\title{
Identifying Supply-Side Constraints to Export Performance in Ecuador: An Exercise with Investment Climate Survey Data
}

\author{
Paulo Correa \\ (ECSPF) \\ Mariam Dayoub \\ (LCSPF) \\ Manuela Francisco \\ (AFTP4)
}

\begin{abstract}
We apply a Heckman selection model to the 2003-Investment Climate Survey (ICS) to investigate supply-side constraints to export performance at the firm level in Ecuador. To correct for the non-random truncation problem, we use the Heckman selection model to estimate the probability of exporting (export propensity) and the share of total sales that are exported (export intensity) by Ecuadorian firms. A baseline model with 12 independent variables divided into three categories - idiosyncratic characteristics, technology, and business environment - is developed. Three other models are developed with the addition of variables related to trade integration, business environment, and infrastructure. Results corroborate with the hypothesis implicit in the Heckman model, which considers both decisions made by a firm - whether to export, and how much of its sales to export - to be interdependent. In the Ecuadorian case, three important results for the firm's export performance are found: technology matters; infrastructure does not; and trade orientation is significant, with specialized firms tending to have smaller export intensity when having the countries of the Andean Community as their main trade partners, the opposite happening if the U.S. is their main trade partner. We find a robust and stable relationship for export propensity and intensity with size, import of inputs, labor regulations, in-house $R \& D$, quality certification, web-use, and foreign ownership. Also, capacity utilization and trade with the U.S. positively affect export intensity, while trade within the Andean Community has the opposite effect in our outcome variable. No significant relationship was found for the infrastructure variables.
\end{abstract}

Key Words: Ecuador, exports, innovation, foreign networks, business environment, firm level.

\section{World Bank Policy Research Working Paper 4179, March 2007}

The Policy Research Working Paper Series disseminates the findings of work in progress to encourage the exchange of ideas about development issues. An objective of the series is to get the findings out quickly, even if the presentations are less than fully polished. The papers carry the names of the authors and should be cited accordingly. The findings, interpretations, and conclusions expressed in this paper are entirely those of the authors. They do not necessarily represent the view of the World Bank, its Executive Directors, or the countries they represent. Policy Research Working Papers are available online at http:/lecon.worldbank.org. 


\section{Introduction}

The classical case for trade liberalization is usually based on static welfare gains from improved resource allocation. In addition, dynamic gains also are realized over time, since increased competition and innovation may need more time to take effect. The static gains arise with the reallocation of resources to more productive industries and firms, as those resources that are no longer used to produce goods that could be imported at lower prices - while consumers' welfare would rise as their real incomes increase (Harberger, 1959, and Krugman and Obstfeld, 2003). Among the dynamic gains, we have the benefits that arise from accessing better technology, inputs and intermediate goods; taking greater advantage of economies of scale and scope; greater domestic competition; and the availability of favorable growth externalities (Helpman and Krugman, 1999). However, trade liberalization may not lead to the expected static and dynamic gains when market imperfections (e.g., rigidities in the labor market, sunk-costs, and incomplete financial markets) prevent resources from being efficiently reallocated and economic resources may be either unemployed or underemployed (Bhagwati, 2002). In addition, the realization of the gains from trade liberalization depends on the supply capacity of the liberalizing economy (Redding and Venables, 2003). It has been increasingly recognized that production cost, quality, and variety of goods and services are three major factors for the creation of new opportunities for workers and entrepreneurs, thereby determining the net benefits from trade liberalization (Hoekman and Javorcik, 2004).

Under inadequate market conditions, therefore, trade liberalization alone is not necessarily the best policy and public interventions targeted to correct such market failures and facilitate the adjustment (i.e., increase labor and capital mobility) are potentially recommendable complements (Hoekman and Javorcik, 2004). For firms, it has been acknowledged that policies addressing market failures (instead of firm failures) are preferable. Examples of such policies include favoring firms' access to technology and know-how, and those to remove barriers to entry and exit from markets (Cordoba et al., 2005). Since most of the adjustment costs are borne by the labor market, distinct policies focusing on workers have been tried. For instance, training in the form of on-thejob learning has been proven to be more effective than classroom training. Also, jobsearch support programs can be very effective in developing countries, and include employment services, and the offering of placement information and counseling (OECD, 2004). Finally, labor mobility can also be impaired by the cost of exiting a job, urging for less rigid labor markets. It is less clear, however, which complementary measures should be taken to develop the internal supply of exportable goods, fully unleashing the country's comparative advantages. The first difficulty is identifying which marketfailures are "bidding" obstacles to the expansion of exports or to the probability of a firm becoming an exporter.

This paper tries to identify the supply-side constraints to export performance in Ecuador. The negotiations of a free-trade agreement (FTA) between Ecuador and the U.S. are currently frozen. However, their continuation and the eventual agreement signature by both parties seems to be inevitable, since negotiations regarding the FTAs U.S.-Peru and U.S.-Colombia were completed in 2005 and 2006, respectively. In addition, the U.S. is Ecuador's main trade partner and source of foreign direct investment 
(FDI). Indeed, further trade integration is a promising initiative, as Ecuador's unrealized trade potential is estimated to be large (Word Bank, 2004) and export-oriented enterprises tend to perform much better than non-exporting firms: on average, exporters are four times larger and six years older than non-exporters; have total sales per worker almost 40 percent higher than non-exporters; pay wages that are, on average, 45 percent higher than non-exporters; on average, the share of exporters that used the web is 50 percent larger than the share of non-exporters; 83 percent of exporters offered training to their permanent staff, a share 32 percent larger than the share of non-exporters offering it; and the share of exporters with productive plants abroad is four times larger than the share of non-exporters.

The materialization of this trade potential in Ecuador is jeopardized, however, by the poor conditions of the "investment climate." Power outages, for example, affected 86 percent of manufacturing firms in Ecuador and cost 7 percent of sales of exporting firms. Current financial intermediation by the private sector corresponds to only 15 percent of GDP, roughly half the volume before the financial crisis. A R\&D share of GDP of 0.1 percent, inferior to that of Colombia and Peru - close competitors in the U.S. market indicates that firms may lack the appropriate knowledge to enter new product markets. Customs clearance for exports takes on average 8.7 days, three times longer than Honduras and Guatemala, also lower-middle-income countries. Addressing all inadequacies of the investment climate at the same time is obviously impossible. Therefore, if the Government of Ecuador decides to implement complementary policies to develop the internal supply of exportable goods and facilitate the realization of the potential gains from trade, what should be its priorities?

In this paper, we try to identify the main constraints to the development of internal supply of exports in Ecuador by using the 2003 Investment Climate Survey to estimate a Heckman selection model of two interdependent decisions: (i) whether a firm exports or not (the probability to export); and, (ii) how much to export (the proportion of total sales to export or export intensity). From our point of view, this is an improvement in the standard approach found in the literature that estimates two independent models: a Probit (for the probability of exporting) and a Tobit (for export intensity). Similar efforts to estimate the impact of the "investment climate" on export performance have also been done for other countries, including China (Dollar et al., 2003) and Brazil (Fajnzylber, 2004).

The reminder of the paper is organized as follows. The next section provides a brief overview of previous studies on the micro-determinants of the export performance of firms, with a focus on firm size, the industry to which a firm belongs, and technology. Section three provides a descriptive analysis of the ICS data. Section four presents the econometric specification and the conceptual framework, detailing the four models developed in this exercise. Section five presents and discusses the estimations results and Section six concludes. The main conclusions were that technology is an important driver of exports for Ecuadorian firms and those that perform in-house R\&D, have a quality certification, access the internet, and/or import inputs are more likely to become exporters and to present higher export intensities. Also, trade orientation is a significant determinant of firms' export performance, with specialized firms tending to have smaller 
export intensities when having the countries of the Andean Community as their main trade partners, and the opposite happening if the U.S. is their main trade partner. Surprisingly, infrastructure does not matter, since none of the infrastructure variables were statistically significant.

\section{Theory}

During the past decade, new literature began to develop introducing the microeconometrics of international trade. The increasing availability of large micro-datasets has triggered research at the firm level instead of at the country or the industry levels. These studies investigated various features of the exporting determinants and several aspects have been identified as major factors of export propensity and intensity. The main findings related to size, industry, and technology are summarized below.

\subsection{Size}

Traditionally, most research on the determinants of export performance have focused on firm size (measured in terms of employment). ${ }^{1}$ The relationship between firm size and exports has been extensively studied. ${ }^{2}$ In the literature, economies of scale, higher capacity for taking risks, more opportunities to raise capital at lower costs, own marketing, R\&D resources, and larger total sales have been identified as causes for a positive impact of size on export performance. Entering a foreign market may involve some level of fixed costs (even some sunk costs), which require a minimum firm size. But, beyond a point, size is not expected to influence the export behavior of firms.

According to Wagner (2001), the threshold point occurs when coordination costs cause a firm's further expansion to be non-profitable. Most studies for both developing and developed countries found a non-linear relationship between size and exports. ${ }^{3}$ Wakelin (1998) argues that this non-linear relationship may occur due to the existence of very large firms, which can be more orientated towards the domestic market as a result of, for example, domestic monopolies that give them no incentives to export. ${ }^{4}$ In addition, Lefebvre and Lefebvre (2001) point out that some small firms may be very competitive in their market niches, whereas some medium firms may find it difficult to compete with large rivals occupying dominant market positions.

\footnotetext{
${ }^{1}$ Few studies, such as Kumar and Siddharthan (1994), Sterlacchini (1999), and Lefebvre et al. (1999), used annual sales as a proxy for firm's size.

${ }^{2}$ See, for example, Bonaccorsi (1992), and Kumar and Siddharthan (1994).

3 A number of studies found an inverted U-shape relationship between size and exports. For example, Wakelin (1998), Bernard and Jensen (1999), Roper and Love (2002), Bleaney and Wakelin (2002), Cassiman and Martinez-Ros (2003), and Barrios et al. (2003) found such relationship between firm size and export propensity. Wagner (1995), Wakelin (1998), Lefebvre et al. (1998), Cassiman and Martinez-Ros (2003), and Barrios et al. (2003) found such non-linear relationship between firm size and export intensity.

${ }^{4}$ An opposite argument is that a large domestic market with critical customers can support the development of competitive advantages, which can be exploited in foreign markets (Porter, 1990).
} 


\subsection{Industry}

In a firm-level analysis of export performance, the industry to which a firm belongs is an important export determinant given that inter-industry features affect firms' opportunities to export differently. Glejser et al. (1982) argue that a high domestic market concentration could negatively affect the share of exports in firms' total sales for two reasons: (i) it allows major firms to harvest the possible economies of scale in the domestic market; and, (ii) dominant firms can exploit monopolistic prices in the home market whereas they might become price-takers in foreign markets.

Another feature concerns the patterns of technological change, which is highly industry-specific (Pavitt, 1984). ${ }^{5}$ To the extent that innovative activities have an impact on firms' exporting probability, one must account for industrial patterns of technological change. ${ }^{6}$ Furthermore, if different regions within a country are strongly specialized in particular industrial activities, the impact of the industry effect on firms' exporting propensity is reinforced by agglomeration economies. Bechetti and Rossi (2000) argue that firms located in "Marshallian districts" benefit from a cost reduction when entering foreign markets because of external economies in the provision of exporting services and information exchange on foreign customers. ${ }^{7}$ They found that, in Italy, the location of small and medium enterprises in industrial districts increases both their probability of exporting and their export intensity. In addition, positive externalities can be obtained through networking and formal integration with other firms. They also found that the affiliation of a firm with an industrial or business group increases its financial and commercial capabilities and, thus, its propensity to export, especially when the business group operates internationally.

\subsection{R\&D, Innovation, and Technological Capabilities}

While there is considerable macroeconomic evidence that differences in innovation can affect firms' export performance, the existing literature on microeconomic empirical studies yields somewhat mixed results. ${ }^{8}$ Hirsch and Bijaoui (1985) found a significant and positive relationship between innovation (measured as the share of R\&D employees) and export propensity and intensity in a sample of 111 Israeli firms. Using a sample of 250 Swedish firms, Braunerhjelm (1996) found a positive association between R\&D expenditure and export intensity. ${ }^{9}$ Moreover, Bleaney and Wakelin (2002) report that both innovative and non-innovative firms in sectors with high ratios of R\&D expenditure to output are more likely to export than firms in sectors in which this share is low.

\footnotetext{
${ }^{5}$ Pavitt (1984) identifies four industry patterns of technological change: (i) supplier dominated; (ii) specialized suppliers; (iii) scale intensive; and, (iv) science based.

${ }^{6}$ See section 2.3 .

${ }^{7}$ The positive effect of geographical agglomeration on export performance will be higher if local firms compete in segmented foreign markets or when there are strong complementarities among them (in both production and commercial activities).

${ }^{8}$ See, for example, Fagerberg (1988).

${ }^{9}$ These 250 firms represented around 40 percent of the total employment in the Swedish manufacturing industry.
} 
Both Sterlacchini (1999) and Nassimbeni (2001) estimated the effect of several technological indicators on exports for a sample of small and medium firms in Italy. They found that the share of total sales spent on design and engineering, the technological level of capital stock, and product innovations are positively related to export propensity. On the other hand, Cassiman and Martinez-Ros (2003), based on data for the Spanish manufacturing sector, found that process innovations are more important drivers of export intensity than product innovations. Similar conclusions were found by Lefebvre et al. (1999) when estimating export intensity of small and medium Canadian firms that export to markets other than the U.S. In addition, Roper and Love (2002), using a sample of UK and German firms, tested three measures of indirect innovation externalities (from the sector firms belong to, inter-sector, and supply-chain spillovers), obtaining a positive relationship between innovation and export propensity and intensity.

On the other hand, Willmore (1992), using a sample of multinational firms in Brazil, found no significant role for R\&D expenditures as a determinant of exports. In the same line, Ito and Pucik (1993) found that the ratio of R\&D expenditures to total sales was a significant determinant of export intensity only when size (total assets) was dropped from the regression. ${ }^{10}$ Kumar and Siddharthan (1994) found a significant effect of R\&D expenditures on the export propensity of 640 Indian firms for the period 19881990, but this held only for firms in low- and medium-technology industries.

An interesting approach of technological capabilities is related to the performance of R\&D in the industrial plant, namely "in-house R\&D." Roper and Love (2001), working with a dataset for the Republic of Ireland, found that in-house R\&D was the most important (and positive) technological variable in the export intensity equation for domestically-owned firms. However, when considering only foreign-owned firms, R\&D conducted elsewhere in the group (typically outside of Ireland) proved to be the most significant (and positive) technological variable in their export intensity model.

According to Nassimbeni (2001), these inconsistent results may reflect the inappropriate use of R\&D as a measure of innovation, as pointed out by Wakelin (1998). He argues that specific R\&D processes rarely take place in small firms; for these firms "innovation is mostly exogenous and takes the form of incremental (often imitative) modifications of existing products or processes" (Nassimbeni, 2001:248). In these cases, $\mathrm{R} \& \mathrm{D}$ is only a partial measure of technology because it does not take into account incremental improvements of products and processes observed in small and medium firms that do not have a formal R\&D department.

To overcome this limitation, Wakelin (1998) used data from the "Science Policy Research Unit/SPRU” innovation survey, which defines innovation as "the successful commercial introduction of new or improved products, process or materials in the market." Working with two different samples (one for innovative firms and the other for non-innovative firms), she concluded that small innovative firms are less likely to export and more likely to serve domestic markets than small non-innovative firms. On the other

\footnotetext{
${ }^{10}$ A criticism to their study is that they used OLS estimates, which can be downward-biased in the exports to sales ratio if it has a large number of observations in its lower limit (firms that do not export).
} 
hand, for large firms, the more innovations they develop the higher the probability of exporting. Wakelin's interpretation is that the cost of entering foreign markets is higher for small firms, which prefer to explore domestic markets. Furthermore, innovative activities positively affected export intensity.

Another approach analyzes technological capabilities of firms, defined as the technical, managerial, and organizational skills to generate and manage technological change. Romijn (1997) affirms that innovations developed by small firms "predominantly consist of practical, shop floor-based and problem-solving [adjustments] involved in setting, running, maintaining, repairing, and making minor changes to technology in response to local conditions that are different from the circumstances under which the technology was developed." ${ }^{11}$ Wignaraja and Ikiara (1999) and Wignaraja (2001) used an index that considered various components of technological capabilities, including product and process improvements, linkages, and investment in new equipment. Using firm-level data from Kenya and Mauritius, respectively, they found a positive and significant association between this innovative index and the firm's export performance. However, both studies are based on very small samples (around 40 firms) and use OLS estimates.

The inconsistent findings regarding innovation in the reviewed literature suggest that results have been strongly influenced by specificities of analyzed contexts (e.g., countries and sectors) and by methodologies in terms of measures and models.

\subsection{Other Determinants}

In addition to size, industry, and technology, other variables can be relevant to explain firms' export propensity and intensity. One example is firm's age. It is a commonly used variable to model a firm's export performance. The interpretation of the coefficient, however, may be unclear. It may be considered that firms seek foreign markets when expansion possibilities in the domestic market are exhausted. However, if new firms are founded on the basis of innovation, younger firms may have comparative advantages with respect to older firms to enter foreign markets. Furthermore, new firms may operate in niche markets with small domestic demands and, thus, have an exportoriented production. This fact can be illustrated by both Smith et al. (2002) and Barrios et al. (2003), who found a positive sign for the age coefficient in their models for export propensity and intensity for Danish firms and the Spanish manufacturing sector, respectively. Nevertheless, the opposite was also found in the literature. Working with Indonesian manufacturing firms, a negative coefficient for the age variable was found for export intensity and export propensity by Ramstetter (1999) and Sjoholm (2003). The explanation for this negative sign lies on the fact that old establishments founded under heavy import substitution policies focused on domestic markets and were less likely to export.

Other examples are variables that capture firms' willingness to take risks to operate in foreign markets. Publicly listed companies with greater financial solvency and/or limited responsibility in terms of liabilities (compared with personal ownership)

${ }^{11}$ See p.359. 
are expected to be better suited to take risks in foreign markets and, as a result, have a higher likelihood to become exporters and to have higher export intensity. Smith et al. (2002) found that the coefficient for publicly listed companies was positively and significantly related with both the export propensity and the export intensity of Danish firms.

Foreign-owned companies are also expected to be more likely to export than domestic-owned enterprises, because they have greater access to networking with foreign markets. Ramstetter (1999) found that foreing-owned firms in Indonesia have a higher share of their output exported in comparison with domestically-owned firms. Roper and Love (2002) and Cassiman and Martinez-Ros (2003) also found this relationship for the Irish and the Spanish manufacturing sectors, respectively. Their findings show that foreign-owned firms are much more likely to export and to export larger shares of their total sales than domestically-owned companies.

According to Roberts and Tybout (1997), foreign networks decrease the firm's cost for collecting information on new markets. There are several channels through which foreign networks can develop, including imports. Thus, imports might be one determinant of exporting propensity. Sjoholm (2003), using imports of intermediate products as one of his proxies for foreign networks, found that this variable has a positive and significant coefficient in an Indonesian firm's probability to start exporting. In addition, Pant (1993) and Dholakia and Kapur (1999, 2004) found a positive and significant relationship between import intensity and export intensity for Indian firms, using a dataset of 557 firms for 1991-92 and 1995-96, respectively. They concluded that the liberalization of imports was itself an export-promoting factor in India.

\section{Descriptive Analysis}

The Investment Climate Survey (ICS) for Ecuador sampled 441 firms in 2003 of which 134 firms (30.4 percent) exported in 2002. Table 1 compares exporters with nonexporters in terms of region, industry, and size. ${ }^{12}$ With respect to region, most firms (around 60 percent) in Manabi exported in 2002, while a small share of enterprises (5 percent) located in Tungurahua sold their products to foreign markets in that year. In the three other regions, exporters responded by 42 percent (Azuay), 31 percent (Pichincha), and 28 percent (Guayas) of total regional firms in 2002. When sampled firms are grouped by industry, it is interesting to notice that, in every category, at least 25 percent of firms exported in 2002. ${ }^{13}$ Another interesting information is that the larger the size category, the higher the share of 2002 exporters.

\footnotetext{
${ }^{12}$ Regions: (i) Tungurahua; (ii) Azuay; (iii) Guayas; (iv) Manabi; and, (v) Pichincha. Industry categories: (i) oil-derived products; (ii) food and beverages; (iii) apparel, textiles and leather; (iv) wood and furniture; (v) chemical products; and, (vi) metallic products.

${ }^{13}$ Considering the share of medium- and high-technology products in Ecuador's total exports, it increased from 0.7 percent in 1990 to 5.2 percent in 2001. In Latin America as a whole, this share increased from 8.9 percent in 1990 to 17.0 percent in 2001.
} 
Table 1: Descriptive statistics for Ecuadorian firms (in percentage)

\begin{tabular}{lrrr}
\hline Group & Number of firms & Exporters (percent) & Non-Exporters (percent) \\
\hline Region & & & \\
Azuay & 31 & 42 & 58 \\
Guayas & 158 & 28 & 72 \\
Manabi** & 17 & 59 & 41 \\
Pichincha & 213 & 31 & 69 \\
Tungurahua*** & 22 & 5 & 95 \\
\hline Industrial Sector & & & \\
Oil products & 49 & 39 & 61 \\
Food and beverage & 113 & 29 & 71 \\
Apparel, textiles and leather & 95 & 30 & 61 \\
Wood and furniture & 33 & 39 & 74 \\
Chemical products & 77 & 26 & 73 \\
Metallic products & 74 & 27 & 98 \\
\hline Size (Employees) & & & 87 \\
Less than 10*** & 40 & 2 & 80 \\
From 10 to 20*** & 91 & 13 & 61 \\
From 21 to 50*** & 136 & 20 & 34 \\
From 51 to 100* & 77 & 69 & \\
More than 100*** & 97 & 66 & \\
\hline
\end{tabular}

Notes: Sample equals 441 firms. Data for year 2002. *Exporters' share is statistically different from the rest of the sample at the 10 percent level. **Exporters' share is statistically different from the rest of the sample at the 5 percent level. ${ }^{* * *}$ Exporters' share is statistically different from the rest of the sample at the 1 percent level.

Source: ICS-Ecuador.

Another possible way of comparing exporters with non-exporters is to verify the means of some variables for each of them. As previously discussed, on average, exporters hire almost four times more employees (and pay wages that are, on average, 45 percent higher) than non-exporters. In addition, on average, exporters are six years older than non-exporters. Thus, it seems that older firms are more likely to explore business opportunities in foreign markets because they either accumulated experience over time or needed new markets to sell their products. With respect to quality certification, 31 percent of exporters had a quality certificate in 2002, a share three times higher than the one for non-exporters. This may reflect requirements to comply with international quality standards in order to supply foreign markets. Finally, comparing exporters to nonexporters in 2002, we have: (i) the share of exporters that used the web was 50 percent larger than the share of non-exporters; (ii) on average, 83 percent of exporters offered training to their permanent staff, a share 32 percent larger than the share of non-exporters offering it; (iii) the share of exporters with loans was 20 percent higher than the share of non-exporters, which can be related to a larger share of exporters that are listed companies; and, (iv) the share of exporters with plants abroad was four times larger than the share of non-exporters (Table 2).

Table 3 describes exporters in terms of location, industry, and size. With respect to region, most exporters were located either in Pichincha (49 percent) or in Guayas (33 percent). In Pichincha, 36 percent of exporters belong to the apparel, textile, and leather sector. Pichincha is the region where Quito, Ecuador's capital, is located and where its textile cluster developed “(...) Succeeding in creating a maquiladora industry within this 
sector that exports to other countries in the [South American] region” (Fonseca, 2003). In Guayas, firms mostly exported fruits (e.g., bananas and mangos) and seafood (e.g., fish and shrimp) using the infrastructure available in the port of Guayaquil. As a result, almost 50 percent of Ecuador's exporters were either part of the apparel, textile, and leather sector or the food and beverage sector. In addition, 15 percent of its exporters were part of each of the following primary sectors: oil, chemicals, or metallic products. With respect to size (in terms of employment), statistics show one more time what was previously discussed: the share of exporters increases as firm size increases.

Table 2: Means of selected variables for Ecuadorian exporters and non-exporters

\begin{tabular}{lcc}
\hline Characteristic & Exporters & Non-Exporters \\
\hline Employees*** & 169 & 56 \\
Wage per employee (US\$ per month)** & 402 & 277 \\
Age (years)*** & 26 & 20 \\
Quality certificate (percent)*** & 31 & 11 \\
Web-use (percent)*** & 72 & 48 \\
Training (percent)*** & 83 & 63 \\
Loan (percent)*** & 82 & 69 \\
Plant abroad (percent)*** & 37 & 9 \\
Publicly listed company S.A. (percent)*** & 63 & 50 \\
\hline
\end{tabular}

Notes: Exporters: 134 firms. Non-exporters: 307 firms. ${ }^{* *}$ Difference in means statistically significant at the 5 percent confidence level. $* * *$ Difference in means statistically significant at the 1 percent confidence level.

Source: ICS-Ecuador.

Table 3: Descriptive statistics for Ecuadorian exporting firms

\begin{tabular}{lrr}
\hline Group & Number of exporters & Share of exporters (percent) \\
\hline Region & 13 & 10 \\
Azuay & 44 & 33 \\
Guayas & 10 & 7 \\
Manabi & 66 & 49 \\
Pichincha & 1 & 1 \\
Tungurahua & & \\
\hline Industrial Sector & 19 & 14 \\
Oil products & 33 & 25 \\
Food and beverage & 29 & 22 \\
Apparel, textiles and leather & 13 & 10 \\
Wood and furniture & 20 & 15 \\
Chemical products & 20 & 15 \\
Metallic products & & \\
\hline Size (Employees) & 1 & 1 \\
Less than 10 & 12 & 9 \\
From 10 to 20 & 27 & 20 \\
From 21 to 50 & 30 & 48 \\
From 51 to 100 & 64 & \\
More than 100 & & \\
\hline
\end{tabular}

Notes: Sample equals 134 exporting firms. Data for year 2002.

Source: ICS-Ecuador.

Still focusing on Ecuadorian exporters, it is interesting to look at the means of selected variables by industrial sector (Table 4). On average, exporters in all sectors hired at least 120 employees, but the most and the least labor-intensive industries were food 
and beverages and apparel, textiles, and leather, respectively. With respect to age, the averages for all sectors were above the average for non-exporters (20 years) and firms in the oil sector were the youngest, while enterprises in the chemical sector were the oldest. ${ }^{14}$ Regarding quality certification, it is notable that the two sectors with the largest shares of firms holding a quality certificate, on average, are food and beverages and wood and furniture. The first sector is related to human consumption and food security and, thus, certification seems to be important to enter foreign markets. On the other hand, wood and furniture requires certification for, at least, two reasons: (i) wood extraction should preserve natural forests (i.e., certification for wood from reforested areas); and, (ii) furniture should meet some quality standards to avoid accidents and guarantee comfort to its users. Most exporters (around 93 percent) in the apparel, textiles, and leather sector had loans in 2002. Finally, when web-use is considered, exporters in the food and beverages and the chemical sectors show the highest average share of internet use, which seems to be an essential tool for successfully trading in foreign markets; however, this share is relatively low in the apparel, textiles, and leather sector, which might be related to the degree of personal business ownership and, thus, lower risk-taking behavior and capital investment.

Table 4: Means of selected variables for Ecuador's exporters by industry

\begin{tabular}{lcccccc}
\hline Characteristic & $\begin{array}{c}\text { Oil } \\
\text { products }\end{array}$ & $\begin{array}{c}\text { Food and } \\
\text { beverages }\end{array}$ & $\begin{array}{c}\text { Apparel, } \\
\text { textiles and } \\
\text { leather }\end{array}$ & $\begin{array}{c}\text { Wood and } \\
\text { furniture }\end{array}$ & $\begin{array}{c}\text { Chemical } \\
\text { products }\end{array}$ & $\begin{array}{c}\text { Metallic } \\
\text { products }\end{array}$ \\
\hline Employees & 127.9 & 299.6 & $119.6^{*}$ & 134.7 & 127.8 & 130.9 \\
Age (years) & $21.5^{*}$ & 25.3 & 26.7 & 26.0 & 28.2 & 25.3 \\
Quality certificate (\%) & 36.8 & 39.4 & $3.4^{* * *}$ & 46.1 & 35.0 & 35.0 \\
Loan (\%) & 73.7 & 87.9 & $93.1^{* * *}$ & 69.2 & 80.0 & 75.0 \\
Publicly listed & & & & & & \\
company S.A. (\%) & 57.9 & 72.7 & 55.1 & 46.2 & 65.0 & 75.0 \\
Web-use (\%) & 63.2 & $84.8^{* * *}$ & $51.7^{* *}$ & 61.5 & $85.0^{*}$ & 80.0 \\
\hline
\end{tabular}

Notes: Sample equals 134 firms. Data for year 2002. *Sector share is statistically different from the rest of the exporter's sample at the 10 percent level. ${ }^{* *}$ Sector share is statistically different from the rest of the exporter's sample at the 5 percent level. ${ }^{* * *}$ Sector share is statistically different from the rest of the exporter's sample at the 1 percent level.

Source: ICS-Ecuador.

Given that Ecuador joined the Andean Community in 1993, reducing its import tariff ceiling from 290 percent to 27 percent, and that Ecuador and the U.S. can re-engage on negotiations regarding their bilateral free trade agreement (FTA), it is relevant looking at the means for some selected variables decomposing our sample of exporters by trade partner. ${ }^{15,16}$ Table 5 disaggregates ten characteristics grouped by: (i) exporters claiming

14 See Table 2.

${ }^{15}$ From 1994 to 2002, the U.S. share in Ecuador's total exports decreased slightly from 40.4 percent to 39.9 percent, while the Andean Community share increased from 10.2 percent to 16.0 percent. In addition, the six most important categories of products exported to the U.S, which accounted for 76.0 percent (in 1994) and 89.2 percent (in 2002) of the total Ecuadorian exports to this country, were: (i) oil; (ii) fruits; (iii) fish, lobsters and shrimp; (iv) flowers; (v) cocoa; and, (vi) coffee and tea. With respect to the Andean community, the most important categories of products exported by Ecuador, which accounted for 67.7 percent (in 1994) and 63.3 percent (in 2002) of Ecuador's total export to this economic bloc, were: (i) oil; (ii) fish, lobsters and shrimp; (iii) vegetal or animal oil; (iv) sugar; (v) vehicles; (vi) iron manufacturing; (vii) cotton; (viii) pharmaceuticals; and, (ix) cereals. 
the U.S. as their first, second, or third main trade partner; (ii) exporters claiming an Andean Community country as their first, second, or third main trade partner; (iii) nonexporters; and, (iv) the whole sample. Exporters whose main markets are either the U.S. or the Andean Community have higher averages for all variables in comparison to nonexporters and the total sample. Focusing on exporters whose main market is the U.S. and those whose main market is the Andean Community, we verify that, on average, the share of the former that accesses the internet is 16 percent higher than the share among the latter. But those whose main market is the Andean Community pay wages (per worker) that are, on average, 38 percent higher than wages paid by exporters whose main market is the U.S. This fact can be related to the categories of product mostly exported for these two distinct markets: to the U.S., it is mostly agricultural products; to the Andean Community, while agricultural products are important, the share of manufactured products in the total exports to this economic bloc has been increasing overtime and their production demands more skilled-labor, which is paid higher wages.

Table 5: Means of selected variables for Ecuador's exporters by destiny

\begin{tabular}{lrccr}
\hline Characteristic & \multicolumn{2}{c}{ Exporters } & Non-Exporters & Total \\
\cline { 2 - 3 } & $\begin{array}{c}\text { Main } \\
\text { U.S. }\end{array}$ & $\begin{array}{c}\text { Main Andean } \\
\text { Community }\end{array}$ & & \\
\hline Number of employees & 260.0 & 153.6 & 55.8 & 90.3 \\
Wage per worker (US\$ per month)*** & 317.8 & 440.1 & 277.4 & 314.5 \\
Sales per worker (US\$ 1,000) & 48.3 & 58.2 & 59.0 & 61.1 \\
Age (years) & 27.0 & 26.9 & 19.9 & 21.6 \\
Quality certificate (percent) & 36.6 & 29.7 & 10.7 & 16.8 \\
Web-use (percent)* & 80.5 & 69.2 & 47.9 & 55.1 \\
Training offered (percent) & 75.6 & 85.7 & 63.2 & 69.2 \\
Loan (percent) & 78.1 & 84.6 & 68.7 & 72.8 \\
Plant abroad (percent) & 31.7 & 37.4 & 8.8 & 17.2 \\
Publicly listed company S.A. (percent) & 58.5 & 63.7 & 49.8 & 54.0 \\
\hline
\end{tabular}

Notes: *Mean difference test for U.S. and Andean Community statistically significant at the 10 percent level. ***Mean difference test for U.S. and Andean Community statistically significant at the 1 percent level.

Source: ICS-Ecuador.

The figures in this section indicate that variables considered to be important appear to be determinants of the export decision and the export intensity for firms in the Ecuadorian manufacturing industry. However, other factors may also affect these two decisions made by firms. Thus, in the next section, we continue with an econometric analysis to control for these factors.

\footnotetext{
${ }^{16}$ On May 16, 2006, the U.S. announced that it had frozen negotiations on the FTA with Ecuador after the latter country decided to annul an operating contract with Occidental Petroleum Corporation (OPC). The U.S. considered this action as a violation of the bilateral investment treaty between the nations. However, Ecuadorian authorities have been working on the re-establishment of FTA negotiations with the U.S.
} 


\section{Theoretical BACKground, DATA, AND VARIABLES}

\subsection{Theoretical Background}

The goal of explaining systematic patterns of variation in the export intensity of firms in the Ecuadorian manufacturing industry requires working with a variety of methodological dilemmas. The first is that the observable export intensity is truncated by the fact that many firms were not exporters in 2002, but they may well join the group of exporters in future years. Excluding such "censored" cases would limit our range of observations on the dependent variable (export intensity) to the values above zero. Since several observations are clustered at the lower limit zero (for export intensity), the data on this variable is assumed to be "left-censored."

This said, how could we detect and control for unobserved export intensity selection effects and, thereby, remove this potential bias from our analysis? Research on selection bias suggests that parameter estimates within an uncensored group of firms may be harmed by the failure to account for the true range of values on the decision to export, including that of zero (or no) exports. To the extent that exporting and non-exporting firms differ from each other in systematic ways, the distribution of our dependent variable (export intensity) in the set of uncensored observations is not normal. This heterogeneous distribution of the dependent variable violates the OLS assumption of normal (non-zero) errors, which may hamper the efficiency and accuracy of point estimates of a regression within the uncensored group (Heckman, 1976).

In order to correct for the non-random truncation problem, a variety of techniques has been developed. Two techniques are dominant: (i) the Tobit model; and, (ii) the Heckman selection model. However, these two models rely on different assumptions to explain the processes that lead to the observed outcomes. Tobin (1956), studying households' consumption of luxury goods, assumed that the dependent variable has a number of its values clustered at the limiting value (usually zero). ${ }^{17}$ Tobit models use all observations to estimate the regression, assuming that the outcome can be completely described by a unique reduced form latent (unobserved) variable $\left(y_{i}{ }^{*}\right)$ and the censoring process only constraints the information available. Some of the limitations of this model are: (i) the same set of variables and coefficients determine the probability that an observation will be censored and the value of the dependent variables; and, (ii) it does not allow for a full theoretical explanation of the reasons or causes that make an observation to be censored. Therefore, the Tobit model is:

$$
\begin{array}{ll}
y_{i}^{*}=x_{i} \beta+u_{i}^{*} & \text { if } x_{i} \beta+u_{i}^{*}>0 \\
y_{i}^{*}=0 & \text { if } x_{i} \beta+u_{i}^{*} \leq 0^{18}
\end{array}
$$

\footnotetext{
17 Tobin (1956) developed the Tobit model.

${ }^{18}$ In our exports model, $y_{i}^{*}=0$ if $x_{i} \beta+u_{i}^{*}=0$.
} 
where $y_{i}^{*}$ has observed values in the interval $[0,1], x_{i}$ is a vector of independent variables with coefficients $\beta$ and $u_{i}{ }^{*}$ is the error term (normally distributed with a zero-mean).

In order to address these shortcomings of the Tobit model, sample selection models modify the likelihood function. First, a different set of variables and coefficients determine the probability of censoring and the value of the dependent variable given that it is observed. Second, sample selection models allow for greater theoretical development because observations are said to be censored by some other variable.

The main idea of the Heckman selection model is that the outcome variable $y$ (export intensity) is only observed if some criterion, defined in terms of a variable $z$ (export propensity), is met. The common form of the model has two stages. In the first stage, a dichotomous variable $z$ (export propensity) determines whether or not $y$ (export intensity) is observed, $y$ being only observed if $z=1$. In the second stage, the expected value of $y$ is modeled conditional to it being observed. Thus, we have that $z$ is a dummy variable and a realization of a latent continuous variable $\left(z^{*}\right)$ that has a normally distributed and independent error term (e) with a zero-mean. If $z=1, y$ is observed, being the realization of a second latent variable $\left(y^{*}\right)$, which has a normally distributed and independent error term $(u)$ with a zero-mean. The two error terms ( $e$ and $u$ ) are assumed to have a correlation $\rho(r h o)$ and a normal and bivariate joint distribution. Therefore, the Heckman selection model has the following form:

(i) Selection equation (first stage):

$$
\begin{aligned}
& z_{i}^{*}=w_{i} \alpha+e_{i} \\
& z_{i}=0 \text { if } z_{i}^{*} \leq 0 \\
& z_{i}=1 \text { if } z_{i}^{*}>0
\end{aligned}
$$

(ii) Outcome equation (second stage):

$$
\begin{gathered}
y_{i}^{*}=x_{i} \beta+u_{i} \\
y_{i}=y_{i}^{*} \text { if } z_{i}=1 \\
y_{i} \text { not observed if } z_{i}=0
\end{gathered}
$$

where $z_{i}{ }^{*}$ is the dichotomous variable, $w_{i}$ is a vector of independent variables with coefficients $\alpha, y_{i}^{*}$ is the outcome variable, $x_{i}$ is a vector of independent variables with coefficients $\beta$, and $e_{i}$ and $u_{i}$ are error terms (normally distributed with zero-mean).

It is relevant to state that $\rho(r h o)$, the correlation between error terms $e_{i}$ and $u_{i}$ in the Heckman selection model, is of high interest to the model. When $\rho=0$, the likelihood 
function for the sample selection model can be split into two parts: (i) a Probit for the probability of being selected; and, (ii) an OLS regression for the expected value of $y$ in the selected sub-sample. ${ }^{19}$ We believe that exporting firms differ in systematic ways from non-exporting firms. Thus, the observation of different export intensities cannot be reduced to a unique linear function. This suggests that the Heckman selection model is an improvement in modeling the export intensity variable. In order to confirm this, the Appendix reports results for our basic model using the Tobit selection model (for export intensity). As will be further discussed, the Heckman selection model estimates show the presence of a selection bias and that the significance of independent variables (and not the outcome equation) suggests that export intensity of Ecuadorian firms cannot be explained through a unique linear equation.

\subsection{Data}

This analysis employs data at the firm-level collected by the ICS-Ecuador, a survey performed in 2003 by the World Bank and a private company. In the survey, data were collected using direct interviews with a questionnaire. Only few questions, usually related to accounting, finance, and labor refer to the two previous years (i.e., 2000 and 2001). The survey covered a stratified sample of 441 firms in ten manufacturing sectors, which were grouped in six categories, and five distinct provinces.

In our sample of 441 Ecuadorian firms, the first procedure we adopted with respect to firm size was to look for outliers. We measured firm size in terms of total employment in 2001, which accounts for the number of permanent and temporary workers hired in that year. ${ }^{20}$ The box plot elaborated for this purpose can be found in the Appendix (Figure A1). In order to get more normally distributed data, nine outliers were omitted, whose size was above 500 employees in 2001. MICIP (2002), in an analytical work done with 803 small and medium Ecuadorian enterprises, found that 67.2 percent, 22.6 percent, and 10.4 percent of them had between 1 and 20 employees, between 21 and 50 employees, and more than 50 employees, respectively. ${ }^{21}$ Following this employment ranges, we divided our sample into three size categories (small, medium, and large), trying to keep an even distribution among them, which were, then, used as a proxy for

${ }^{19}$ The likelihood function for the sample selection model is:

$L=\sum_{0} \log \left(1-\Phi_{i}\right)+\sum_{1} \log \Phi\left[\frac{w_{i} \alpha+\rho\left(\frac{y_{i}-x \beta}{\sigma_{11}}\right)}{\left(1-\rho^{2}\right)^{1 / 2}}\right]+\sum_{2}-\frac{1}{2}\left[\log \left(2 \pi \sigma_{22}^{2}\right)\right]+\left[\frac{\left(y_{i}-\beta x_{i}\right)}{\sigma_{22}}\right]^{2}$

When $\sigma=0$, we have the likelihood function of:

(i) A Probit: $L=\sum_{0} \log \left(1-\Phi_{i}\right)+\sum_{1} \log \Phi\left[w_{i} \alpha\right]$

(ii) An OLS: $L=\sum_{1}-\frac{1}{2}\left[\log \left(2 \pi \sigma_{22}^{2}\right)\right]+\left[\frac{\left(y_{i}-\beta x_{i}\right)}{\sigma_{22}}\right]^{2}$

${ }^{20}$ Employment was lagged one period because the causality between this variable and the dependent variables would, otherwise, not be obvious.

${ }^{21}$ The sample of 803 firms estimated the country's proportions of firms in each size category at the 95 percent confidence level. 
firm size in our equations (Table 6). ${ }^{22}$ We chose to use size categories (discrete variables) because our goal is quantifying the differences in export performance of medium and large firms with respect to small firms, given that several services available for Ecuadorian firms frequently depend on their size category. ${ }^{23}$

Table 6: Ecuadorian firms: classification per size category

\begin{tabular}{lccc}
\hline Category & \multicolumn{2}{c}{ Number of employees } & \multicolumn{2}{c}{ Firms } \\
\cline { 2 - 4 } & & Number & Share (percentage) \\
\hline Small & 1 to 19 & 145 & 33.6 \\
Medium & 20 to 54 & 146 & 33.8 \\
Large & 55 to 500 & 141 & 32.6 \\
\hline Total & 1 to 500 & 432 & 100.0 \\
\hline
\end{tabular}

Source: ICS-Ecuador.

Out of the 432 firms kept after cleaning up the data, 126 firms (29.2 percent) exported in 2002. ${ }^{24}$ In the group of exporters, the share of a firm's total sales exported (export intensity) in 2002 was identified.

Table 7 lists the independent variables we considered to be the core variables in explaining export propensity and export intensity of Ecuadorian firms, using a sample of 432 firms surveyed by the ICS in 2003. A correlation matrix for the core variables and the variables to be added later on to our basic model is included in the Appendix (Table A2).

Table 7: List of core variables

\begin{tabular}{|c|c|c|c|c|}
\hline Set & Variable & Unit & $\begin{array}{l}\text { Expected } \\
\text { sign }\end{array}$ & Measure of \\
\hline Firm & Age & Years of operation & + & Experience \\
\hline Idiosyncratic & Medium & Dummy for employees [20, 55[ & + & Efficiency \\
\hline Characteristics & Large & Dummy for employees $[55,500]$ & + & Efficiency \\
\hline \multirow[t]{5}{*}{ Technology } & $R \& D$ & Dummy for in-house R\&D since 2000 & + & Technology \\
\hline & Innovation & $\begin{array}{l}\text { Dummy for process innovation since } \\
2000\end{array}$ & + & Technology \\
\hline & Quality certification & Dummy for quality certificate & + & $\begin{array}{l}\text { Technology } \\
\text { absorption }\end{array}$ \\
\hline & Web-use & Dummy for web-use & + & $\begin{array}{l}\text { Technology and } \\
\text { globalization }\end{array}$ \\
\hline & Imported inputs ${ }^{1}$ & $\begin{array}{l}\text { Share of inputs that were acquired } \\
\text { through direct imports in } 2002\end{array}$ & + & $\begin{array}{l}\text { Technology } \\
\text { absorption }\end{array}$ \\
\hline \multirow{4}{*}{$\begin{array}{l}\text { Business } \\
\text { Environment }\end{array}$} & Listed company & Dummy for publicly listed company & + & Solvency \\
\hline & Loan & Dummy for loan & + & Investment \\
\hline & Foreign ownership & $\begin{array}{l}\text { Dummy for } 50 \text { percent or more of } \\
\text { firm's capital is foreign }\end{array}$ & + & $\begin{array}{l}\text { Foreign } \\
\text { networks }\end{array}$ \\
\hline & Capacity utilization $^{2}$ & Capacity utilization in 2002 (percent) & + & Business cycle \\
\hline
\end{tabular}

Notes: ${ }^{1}$ Used only as an explanatory variable for export propensity. ${ }^{2}$ Used only as an explanatory variable for export intensity.

${ }^{22}$ The firm size "small” was omitted in our equations. Please, refer to section 4.3.

${ }^{23}$ For example, the Banco Nacional de Fomento (National Development Bank) offers special credit lines to be used in the acquisition of fixed capital for firms with less than 20 employees.

${ }^{24}$ Exporter was defined as a firm that exported any positive quantity in 2002. 


\subsection{Model Specification}

\subsubsection{Baseline}

Using the core variables specified in Table 7 and using a Heckman selection model, we developed a basic specification (named baseline) whose test equations for firm $i$ in year $t$ are:

(i) Selection equation (export propensity):

$$
\begin{aligned}
\text { Export Propensity }_{i t}=1 \text { if } & \alpha_{0}+\alpha_{1} \text { Age }_{i t}+\alpha_{2} \text { Medium }_{i t-1}+\alpha_{3} \text { Large }_{i t-1}+\alpha_{4} R \& D_{i t}+ \\
& +\alpha_{5} \text { Innovation }_{i t}+\alpha_{6} \text { Quality certification }_{i t}+\alpha_{7} \text { Web-use }_{i t}+ \\
& +\alpha_{8} \text { Imported inputs }_{i t}+\alpha_{9} \text { Listed company }_{i t}+\alpha_{10} \text { Loan }_{i t}+ \\
& +\alpha_{11} \text { Foreign ownership }_{i t}+e_{i t} \geq 0
\end{aligned}
$$

Export Propensity $_{i t}=0$ otherwise.

(ii) Outcome equation (export intensity):

$$
\begin{aligned}
\text { Export Intensity }_{i t}= & \beta_{0}+\beta_{1} \text { Age }_{i t}+\beta_{2} \text { Medium }_{i t-1}+\beta_{3} \text { Large }_{i t-1}+\beta_{4} R \& D_{i t}+\beta_{5} \text { Innovation }_{i t}+ \\
& +\beta_{6} \text { Quality certification }_{i t}+\beta_{7} \text { Web-use }_{i t}+\beta_{8} \text { Listed company }_{i t}+ \\
& +\beta_{9} \text { Loan }_{i t}+\beta_{10} \text { Foreign ownership }_{i t}+\beta_{11} \text { Capacity utilization }_{i t}+u_{i t} \\
& \text { if Export Propensity }=1 .
\end{aligned}
$$

Export Intensity $_{i t}$ not observed if Export Propensity $=0$.

Age and size are firm's idiosyncratic characteristics likely to affect export performance. The rationale for including age in the model is that experience has been found to positively affect exports. Thus, we expect age to have a positive relationship with both export propensity and export intensity. With respect to size, two categories (Medium and Large) were added to the model because we aim to quantify the differences in export performance of medium and large firms with respect to small firms. ${ }^{25}$ Other empirical studies found that larger firms are relatively more likely to export, which may be related to decreasing average costs. Another possible explanation is that larger firms have been successful in the domestic market, which could increase the probability of being successful in foreign markets. The rationale behind this categorical size choice is that several services available for Ecuadorian firms frequently depend on the size

\footnotetext{
${ }^{25}$ For size measured in terms of employment in 2001, (i) small firms: 1-19 employees; (ii) medium firms: 20-54 employees; and, (iii) large firms: 55-500 employees.
} 
category a firm belongs to. Therefore, we expect these variables to have a positive relationship with both export propensity and export intensity.

With respect to technology, five proxies were included in the model, namely $R \& D$, Innovation, Quality certification, Web-use, and Imported inputs. The first three proxies aim at capturing product quality while the fourth and the fifth may capture the globalization level of a firm and its degree of technology absorption, respectively. Following several empirical studies, we included in-house R\&D, process innovation, and quality certification as technology proxies because they may have a positive effect on the quality of the products and, probably, on a firm's export performance. Based on Clarke (2001), we included a fourth proxy for technology: web-use. The rationale behind this variable is that firms with higher access to the internet are believed to establish and develop contact with current and potential foreign buyers and sellers. In addition, webuse is also a powerful means to obtain information on foreign markets. Thus, we expect web-use to be positively related to firm's export performance. Imported inputs would also be expected to positively affect export propensity, since the acquisition of intermediate goods is believed to be a means of technology absorption in addition to foster good learning opportunities about foreign markets.

Four core variables in the business environment set were included in the baseline model. The first is a dummy variable (Listed company) that equals one if the firm is a publicly listed company, which measures the firm's solvency level. The rationale behind adding this variable to the model is that firms with greater financial solvency are expected to be more willing and able to take the risks of operating in foreign markets than personally-owned businesses. Hence, we predict that the listed company variable will be positively related to both export propensity and export intensity. The second variable (Loan) is also a dummy, which equals one if the firm has a loan. We believe that firms that were able to access credit markets would have invested more in terms of fixed capital, technological processes, and training, which make them more prone to compete in foreign markets. Thus, loan is expected to have a positive effect on a firm's export performance. The third variable is Capacity utilization. In empirical studies, it has been argued that capacity utilization plays an important role in business cycles fluctuations - it is pro-cyclical. ${ }^{26}$ In addition, non-exporters must incur sunk costs to enter foreign markets and firms that have already incurred the sunk start-up costs should be relatively more likely to export in the current period - there would be persistence in trade flows because firms have the incentive to expand exports in order to decrease unitary fixed costs (to recover the sunk costs). ${ }^{27}$ Therefore, the activities of a firm that incurred these sunk costs would be more oriented toward foreign markets. Then, it is plausible to affirm that the decision to start exporting is made based on the long-run. However, business cycles characterize the short-run. As a result, capacity utilization is added only in the output equation and we expect a positive relationship between this explanatory variable and export intensity. ${ }^{28}$ The fourth variable (Foreign ownership) is a dummy variable that

\footnotetext{
${ }^{26}$ See, for example, Boileau and Normandin (1999).

${ }^{27}$ See Roberts and Tybout (1997).

${ }^{28}$ Advancement in using the Heckman selection model is also associated with the fact that we do not take into account the sunk costs a firm must incur to become an exporter in the selection equation. If we were
} 
equals one if at least 50 percent of the firm's capital is owned by foreigners. We would expect foreign ownership to have a positive sign on both equations because it is related to greater interaction with foreign markets. ${ }^{29}$

As discussed before, there are clear industry specific effects on firms' export performance. To control for these effects, we use five industry specific dummies, which aim at capturing price and demand effects. ${ }^{30}$ A drawback from controlling for industry specific effects is that we are likely to underestimate the effects on export propensity and intensity from the included dummies. ${ }^{31}$ Finally, we control for region specific effects by including four provincial dummies in our model. ${ }^{32}$

\subsubsection{Baseline and Business Environment}

Two other business environment variables were added to our baseline model, namely Customs and Labor regulations. These variables are dummies that equal one if a firm considered problems in these two areas to either affect its operations or make it hard for the enterprise to grow. Given that exporting is one of the firm's operations and may be a decision to make when growth occurs, we expect these two independent variables to be negatively related to both export propensity and export intensity.

\subsubsection{Baseline and Trade}

In order to access the impact of trade orientation on an Ecuadorian firm's import intensity, we included two variables in our baseline model. ${ }^{33}$ Both of them reflect exporters' claims on their first, second, or third main trade partner.

The first variable (Main U.S.) is a proxy for trading with the U.S. It is a dummy variable that equals one if a firm considers the U.S. to be its first, second, or third main trade partner. It was added to the model in order to make some inferences on the impacts of the FTA between Ecuador and the U.S. Given that the U.S. (large stable country) mimes a reference on international trade, reducing trade barriers between the Ecuadorian and the American markets means opening the borders of Ecuador to the global market. Hence, we expect a positive relationship between the Main U.S. variable and export intensity.

implicitly recognizing these costs, we would expect capacity utilization to be negatively associated with export intensity since we would consider both eventual exporters - whose exports were output residuals, not sold to the domestic market - and recurrent exporters.

${ }^{29}$ We follow Sjoholm (2003), who used a similar variable when modeling export propensity for an Indonesian firm.

${ }^{30}$ Wood and furniture is the omitted category for industry.

${ }^{31}$ For example, some industries may have several exporters because there are more firms in the "large" size category.

32 Pichincha is the omitted category for region.

33 These variables were included only in the export intensity equation because they were only observed among firms that exported in 2002 (i.e., Export Propensity = 1). 
The second variable (Main Andean Community) proxies the trade between Ecuador and the trade bloc it joined in the early-1990s (the Andean Community). It is a dummy variable that equals one if a firm considers at least one country belonging to the Andean Community to be its first, second, or third main trade partner. In his seminal work, Viner (1950) poses that trade creation occurs when the establishment of a free trade area (as intra-regional import tariffs are lowered) results in a shift from domestic production to importing from one of the bloc members. In this case, a less efficient producer is replaced by a more efficient one. But trade diversion can also occur when imports from a country that does not belong to the bloc are substituted by imports from a bloc member - which is less efficient in production. The Andean Community is getting less open since it was created in 1969 (Foroutan, 1998). In order to access if trading within this bloc provides Ecuadorian firms with any exporting advantage and if there has been trade diversion, the variable Main Andean Community was added to our outcome equation. We predict a negative relationship between this explanatory variable and export intensity. $^{34}$

\subsubsection{Baseline and Infrastructure}

We added three infrastructure variables (Energy, Telecom, and Transportation) to both equations of our baseline model in order to access their significance to the export performance of Ecuadorian firms. Infrastructure proxies were measured as the annual share of energy, telecommunications, and transport interruptions a firm faced in 2002. ${ }^{35}$ These variables capture the quality of infrastructure services (the more interruptions occur, the worse the infrastructure services) offered to Ecuadorian firms and are expected to have a negative effect on both export propensity and export intensity.

\section{EMPIRICAL RESULTS}

Regarding the estimation techniques, we started by running the regressions on the baseline specification - equations (7) and (8) - since there is empirical evidence on the importance of the specified core variables for Ecuadorian firms' export performance. In both stages of the Heckman selection model, five industry and four regional dummies were included. After estimating our baseline equations (7) and (8), we added the other explanatory variables used to develop the other three distinct specifications: (i) baseline + business environment; (ii) baseline + trade; and, (iii) baseline + infrastructure. ${ }^{36}$

Maximum likelihood estimates for the four estimating models are shown in Tables 8 and 9. The reported Wald test for overall significance indicates that, taken

\footnotetext{
${ }^{34}$ Policymakers rely on the infant industry argument to support trade agreements. First, this industry is exposed to regional markets in order to develop over time and, then, it becomes able to compete in the global market. In fact, protecting infant industries can work, but there have been probably more failures than successes.

${ }^{35}$ The creation of these infrastructure variables was done by dividing the number of days a firm faced interruptions in energy, telecommunications, and transportation services by 365 days.

${ }^{36}$ Note that the specification "baseline + trade" does not affect our selection equation (7). It only adds the variables Main U.S. and Main Andean Community to our output equation (8), since only firms that exported in 2002 were able to respond the question regarding their three most important trade partners.
} 
jointly, independent variables' coefficients are significant. Also, the correlation coefficient $(\rho)$ between the error term of the export propensity equation $\left(e_{i t}\right)$ and the error term of the export intensity equation $\left(u_{i t}\right)$ is significantly different from zero. This validates our choice for the Heckman selection model (i.e., the two equations are correlated or interdependent). This is an advancement in the exports at the firm-level literature, since it both corrects for the selection bias problem and innovates in considering the interdependency between the decision to export (for which other studies in the literature commonly use a Probit model) and the decision of which share of total sales to export (for which other studies in the literature commonly use a Tobit model).

Distinct estimations of our selection equation (7) and our output equation (8) are shown in Tables 8 and 9, which report regression results for export propensity and export intensity, respectively. 
Table 8: Heckman estimations on the export propensity of Ecuadorian firms

\begin{tabular}{|c|c|c|c|c|c|}
\hline Set & Variable & Baseline & $\begin{array}{c}\text { Baseline }+ \\
\text { Business } \\
\text { Environment }\end{array}$ & $\begin{array}{c}\text { Baseline + } \\
\text { Trade }\end{array}$ & $\begin{array}{c}\text { Baseline + } \\
\text { Infrastructure }\end{array}$ \\
\hline-- & Constant & $\begin{array}{c}-1.39854 * * * \\
{[-4.57]}\end{array}$ & $\begin{array}{c}-1.49800 * * * \\
{[-4.86]}\end{array}$ & $\begin{array}{c}-1.28850 * * * \\
{[-4.25]}\end{array}$ & $\begin{array}{c}-1.50328 * * * \\
{[-4.78]}\end{array}$ \\
\hline \multirow{3}{*}{$\begin{array}{l}\text { Firm } \\
\text { Idiosyncratic } \\
\text { Characteristics }\end{array}$} & Age & $\begin{array}{c}0.00456 \\
{[1.03]}\end{array}$ & $\begin{array}{c}0.00541 \\
{[1.23]}\end{array}$ & $\begin{array}{c}0.00522 \\
{[1.16]}\end{array}$ & $\begin{array}{c}0.00354 \\
{[0.80]}\end{array}$ \\
\hline & Medium & $\begin{array}{c}0.13335 \\
{[0.73]}\end{array}$ & $\begin{array}{c}0.16765 \\
{[0.90]}\end{array}$ & $\begin{array}{c}0.08967 \\
{[0.50]}\end{array}$ & $\begin{array}{c}0.15893 \\
{[0.87]}\end{array}$ \\
\hline & Large & $\begin{array}{c}0.70340 * * * \\
{[3.98]}\end{array}$ & $\begin{array}{l}0.68806 * * * \\
{[3.77]}\end{array}$ & $\begin{array}{l}0.64831 * * * \\
{[3.60]}\end{array}$ & $\begin{array}{l}0.75784^{* * * *} \\
{[4.26]}\end{array}$ \\
\hline \multirow[t]{5}{*}{ Technology } & R\&D & $\begin{array}{l}0.35796 * * * \\
{[2.63]}\end{array}$ & $\begin{array}{l}0.31865 * * \\
{[2.35]}\end{array}$ & $\begin{array}{l}0.31603 * * \\
{[2.34]}\end{array}$ & $\begin{array}{l}0.38084 * * * \\
{[2.78]}\end{array}$ \\
\hline & Innovation & $\begin{array}{c}0.16186 \\
{[1.12]}\end{array}$ & $\begin{array}{c}0.14505 \\
{[1.00]}\end{array}$ & $\begin{array}{c}0.14403 \\
{[1.01]}\end{array}$ & $\begin{array}{c}0.14904 \\
{[1.04]}\end{array}$ \\
\hline & $\begin{array}{l}\text { Quality } \\
\text { certification }\end{array}$ & $\begin{array}{c}0.38530 * * \\
{[2.26]}\end{array}$ & $\begin{array}{c}0.41740 * * \\
{[2.39]}\end{array}$ & $\begin{array}{c}0.49354 * * * \\
{[2.89]}\end{array}$ & $\begin{array}{c}0.39966 * * \\
{[2.33]}\end{array}$ \\
\hline & Web-use & $\begin{array}{l}0.31229 * * \\
{[2.02]}\end{array}$ & $\begin{array}{l}0.34471^{* *} \\
{[2.18]}\end{array}$ & $\begin{array}{c}0.30816^{* *} \\
{[2.05]}\end{array}$ & $\begin{array}{l}0.32122 * * \\
{[2.13]}\end{array}$ \\
\hline & $\begin{array}{l}\text { Imported } \\
\text { inputs }\end{array}$ & $\begin{array}{c}0.00144 * * * \\
{[4.96]}\end{array}$ & $\begin{array}{c}0.00059 \\
{[0.68]}\end{array}$ & $\begin{array}{c}0.00139 \\
{[0.83]}\end{array}$ & $\begin{array}{l}0.00190^{* * *} \\
{[14.45]}\end{array}$ \\
\hline \multirow[t]{4}{*}{$\begin{array}{l}\text { Business } \\
\text { Environment }\end{array}$} & $\begin{array}{l}\text { Listed } \\
\text { company } \\
\text { Loan }\end{array}$ & $\begin{array}{c}0.10623 \\
{[0.73]} \\
0.37777^{* *} \\
{[2.25]}\end{array}$ & $\begin{array}{l}0.07027 \\
{[0.48]} \\
0.39156^{* *} \\
{[2.31]}\end{array}$ & $\begin{array}{c}0.14337 \\
{[1.01]} \\
0.37488^{* *} \\
{[2.27]}\end{array}$ & $\begin{array}{c}0.09112 \\
{[0.64]} \\
0.36077^{* *} \\
{[2.18]}\end{array}$ \\
\hline & $\begin{array}{l}\text { Foreign } \\
\text { ownership }\end{array}$ & $\begin{array}{c}0.70440 * * * \\
{[2.68]}\end{array}$ & $\begin{array}{l}0.75162 * * * \\
{[2.78]}\end{array}$ & $\begin{array}{c}0.66499 * * * \\
{[3.13]}\end{array}$ & $\begin{array}{c}0.74287 * * * \\
{[3.52]}\end{array}$ \\
\hline & Customs & -- & $\begin{array}{c}0.08006 \\
{[0.55]}\end{array}$ & -- & -- \\
\hline & $\begin{array}{l}\text { Labor } \\
\text { regulations }\end{array}$ & -- & $\begin{array}{l}0.30382 * * \\
{[2.05]}\end{array}$ & -- & -- \\
\hline \multirow[t]{3}{*}{ Infrastructure } & Energy & -- & -- & -- & $\begin{array}{l}-1.76642 \\
{[-1.42]}\end{array}$ \\
\hline & Telecom & -- & -- & -- & $\begin{array}{c}0.10666 \\
{[0.17]}\end{array}$ \\
\hline & Transportation & -- & -- & -- & $\begin{array}{c}-2.71979 \\
{[-0.72]}\end{array}$ \\
\hline \multicolumn{2}{|l|}{ No. observations } & 431 & 431 & 431 & 431 \\
\hline \multicolumn{2}{|l|}{ Log likelihood } & -764.30 & -759.31 & -761.09 & -753.45 \\
\hline \multicolumn{2}{|l|}{ Wald $\chi^{2}$ (d.f.) } & $92.76(20)$ & $112.69(22)$ & $342789.18(22)$ & $222.56(23)$ \\
\hline \multicolumn{2}{|c|}{ Likelihood test $\chi^{2}(\rho=0)$} & 64.81 & 66.96 & 51.00 & 65.87 \\
\hline
\end{tabular}

Notes: *Significant at a 10 percent level. **Significant at a 5 percent level. ${ }^{* * * \text { Significant at a } 1 \text { percent }}$ level. Z-value is in brackets. Small is the omitted variable for size category. For brevity purposes, sector and regional variables were not included in Table 8. The wood and furniture sector is the omitted category for industry. Pichincha is the omitted category for region. 
Table 9: Heckman estimations on the export intensity of Ecuadorian firms

\begin{tabular}{|c|c|c|c|c|c|}
\hline Set & Variable & Baseline & $\begin{array}{c}\text { Baseline + } \\
\text { Business } \\
\text { Environment }\end{array}$ & $\begin{array}{c}\text { Baseline + } \\
\text { Trade }\end{array}$ & $\begin{array}{c}\text { Baseline }+ \\
\text { Infrastructure }\end{array}$ \\
\hline -- & Constant & $\begin{array}{c}-53.71638 * * * \\
{[-3.88]}\end{array}$ & $\begin{array}{c}-58.85900^{* * *} \\
{[-4.07]}\end{array}$ & $\begin{array}{c}-62.91873^{* * *} \\
{[-4.50]}\end{array}$ & $\begin{array}{c}-51.88239 * * * \\
{[-3.84]}\end{array}$ \\
\hline \multirow{3}{*}{$\begin{array}{l}\text { Firm } \\
\text { Idiosyncratic } \\
\text { Characteristics }\end{array}$} & Age & $\begin{array}{c}0.23166 \\
{[1.19]}\end{array}$ & $\begin{array}{c}0.18184 \\
{[0.95]}\end{array}$ & $\begin{array}{l}0.25513 \\
{[1.34]}\end{array}$ & $\begin{array}{c}0.23542 \\
{[1.25]}\end{array}$ \\
\hline & Medium & $\begin{array}{c}7.42555 \\
{[0.85]}\end{array}$ & $\begin{array}{l}6.82460 \\
{[0.81]}\end{array}$ & $\begin{array}{c}10.08919 \\
{[1.32]}\end{array}$ & $\begin{array}{c}5.94396 \\
{[0.77]}\end{array}$ \\
\hline & Large & $\begin{array}{l}27.89876 * * * \\
\quad[3.54]\end{array}$ & $\begin{array}{l}28.09475 * * * \\
{[3.68]}\end{array}$ & $\begin{array}{c}29.01797 * * * \\
{[3.68]}\end{array}$ & $\begin{array}{c}25.94384 * * * \\
{[3.38]}\end{array}$ \\
\hline \multirow[t]{2}{*}{ Technology } & $\begin{array}{l}\text { R\&D } \\
\text { Innovation }\end{array}$ & $\begin{array}{c}15.22227 * * * \\
{[2.57]} \\
6.61940 \\
{[0.98]}\end{array}$ & $\begin{array}{c}14.84107^{* *} \\
{[2.50]} \\
8.64884 \\
{[1.34]}\end{array}$ & $\begin{array}{c}17.18669 * * * \\
{[2.96]} \\
8.64862 \\
{[1.43]}\end{array}$ & $\begin{array}{c}14.98598 * * * \\
{[2.58]} \\
4.51499 \\
{[0.74]}\end{array}$ \\
\hline & $\begin{array}{l}\text { Quality } \\
\text { certification } \\
\text { Web-use }\end{array}$ & $\begin{array}{c}17.15956^{* *} \\
{[2.28]} \\
14.89787^{* *} \\
{[2.10]}\end{array}$ & $\begin{array}{c}15.40446^{* *} \\
{[2.09]} \\
15.78313^{* *} \\
{[2.30]}\end{array}$ & $\begin{array}{c}14.40015^{*} \\
{[1.89]} \\
14.59645^{* *} \\
{[2.29]}\end{array}$ & $\begin{array}{c}17.93832^{* *} \\
{[2.45]} \\
13.73288^{* *} \\
{[2.15]}\end{array}$ \\
\hline \multirow[t]{6}{*}{$\begin{array}{l}\text { Business } \\
\text { Environment }\end{array}$} & $\begin{array}{l}\text { Listed } \\
\text { company }\end{array}$ & $\begin{array}{c}4.10308 \\
{[0.64]}\end{array}$ & $\begin{array}{c}5.13066 \\
{[0.81]}\end{array}$ & $\begin{array}{l}2.23912 \\
{[0.37]}\end{array}$ & $\begin{array}{c}4.20518 \\
{[0.69]}\end{array}$ \\
\hline & Loan & $\begin{array}{l}19.23982 * * * \\
{[2.56]}\end{array}$ & $\begin{array}{c}17.34861^{* *} \\
{[2.29]}\end{array}$ & $\begin{array}{c}20.88425 * * * \\
{[3.00]}\end{array}$ & $\begin{array}{c}20.83855 * * * \\
{[2.95]}\end{array}$ \\
\hline & $\begin{array}{l}\text { Foreign } \\
\text { ownership }\end{array}$ & $\begin{array}{c}30.60859 * * * \\
{[3.05]}\end{array}$ & $\begin{array}{c}26.99725^{* * * *} \\
{[2.63]}\end{array}$ & $\begin{array}{c}31.61106^{* * *} \\
{[3.52]}\end{array}$ & $\begin{array}{c}29.94246 * * * \\
{[3.36]}\end{array}$ \\
\hline & $\begin{array}{l}\text { Capacity } \\
\text { utilization }\end{array}$ & $\begin{array}{l}0.01199 * \\
{[1.69]}\end{array}$ & $\begin{array}{l}0.07129 * * \\
{[2.37]}\end{array}$ & $\begin{array}{l}0.09270 * * \\
{[2.26]}\end{array}$ & $\begin{array}{c}-0.00533^{* * *} \\
{[-10.79]}\end{array}$ \\
\hline & Customs & -- & $\begin{array}{c}-1.00510 \\
{[-0.16]}\end{array}$ & -- & -- \\
\hline & $\begin{array}{l}\text { Labor } \\
\text { regulations }\end{array}$ & -- & $\begin{array}{l}17.14290 * * * \\
{[2.68]}\end{array}$ & -- & -- \\
\hline \multirow[t]{2}{*}{ Trade } & Main U.S. & -- & -- & $\begin{array}{c}2.94983^{* * *} \\
{[3.14]}\end{array}$ & -- \\
\hline & $\begin{array}{l}\text { Main Andean } \\
\text { Community }\end{array}$ & -- & -- & $\begin{array}{c}-8.89590 * * * \\
{[-5.20]}\end{array}$ & -- \\
\hline \multirow[t]{3}{*}{ Infrastructure } & Energy & -- & -- & -- & $\begin{array}{c}-16.72563 \\
{[-0.32]}\end{array}$ \\
\hline & Telecom & -- & -- & -- & $\begin{array}{c}-29.74419 \\
{[-1.13]}\end{array}$ \\
\hline & Transportation & -- & -- & -- & $\begin{array}{c}12.77126 \\
{[0.08]}\end{array}$ \\
\hline \multicolumn{2}{|l|}{ Censored obs. } & 305 & 305 & 305 & 305 \\
\hline \multicolumn{2}{|l|}{ Uncensored obs. } & 126 & 126 & 126 & 126 \\
\hline \multicolumn{2}{|l|}{ Log likelihood } & -764.30 & -759.31 & -761.09 & -753.45 \\
\hline \multicolumn{2}{|l|}{ Wald $\chi^{2}$ (d.f.) } & $92.76(20)$ & $112.69(22)$ & $342789.18(22)$ & $222.56(23)$ \\
\hline \multicolumn{2}{|c|}{ Likelihood test $\chi^{2}(\rho=0)$} & 64.81 & 66.96 & 51.00 & 65.87 \\
\hline
\end{tabular}


Most variables have statistically significant coefficients and support the hypotheses we based the development of our model on. Thus, we were able to replicate for Ecuadorian firms most of the established results of the literature, but with the advancement of using the Heckman selection model. Results are robust and stable, which means that they are (for the core variables), with one exception (Imported inputs), similar in the four different estimations.

Large firms, with at least 55 employees, are relatively more likely to export and to export a larger share of their total sales than small firms (those with less than 20 employees). In sum, if a firm lies below a minimum size, it probably does not have sufficient managerial, financial, and/or commercial capabilities to become an exporter. These positive and significantly coefficients on Large are consistent with: (i) the view of decreasing fixed costs; (ii) the theory that considers large firms successful in domestic markets and, thus, more prone to succeed in foreign markets; and, (iii) the idea of sunk costs that need to be incurred by firms so that they can explore foreign commercial opportunities, thus requiring a minimum firm size. However, a similar consideration cannot be made with respect to medium-sized firms. This positive result for size reflects what was found in other researches in export performance at the firm-level, such as Schlegelmilch and Crook (1988) for export intensity of the British mechanical engineering firms, Wakelin (1998) studying both the British and the German manufacturing sector, Dholakia and Kapur (1999) for Indian firms, Bleaney and Wakelin (2001) considering the British manufacturing sector, Roper and Love (2002) for the Irish manufacturing firms, Sjoholm (2003) modeling export propensity of Indonesian firms, and Cassiman and Martinez-Ros (2003) in their study of the Spanish manufacturing sector. $^{37}$

Some important remarks can be made on technology, which can be considered an important driver of exports. ${ }^{38}$ Ecuadorian firms that perform in-house R\&D, have a quality certification (such as an ISO-certificate), access the internet, and/or import inputs are more likely to become exporters and to present higher export intensities. Given that in-house $R \& D$ and quality certification are proxies for product quality, these findings are consistent with the idea that high-quality goods make firms more likely to sell these items abroad and, thus, they present higher export intensities - in addition to the fact that, for several products, a quality certification is mandatory if a firm wants to access foreign markets. However, to acquire a quality certification, a firm must incur high sunk costs, which make its acquisition prohibitive for small and medium enterprises. For example, since obtaining an ISO-certification can cost a small to medium enterprise from US $\$ 25,000$ to US $\$ 50,000$, one possible explanation is that small and medium firms are unable to afford it. In the literature, no records of using a quality certification variable were found; however, similar results for in-house R\&D were obtained by Roper and Love (2001, 2002) and Cassiman and Martinez-Ros (2003). With respect to web-use, our

\footnotetext{
${ }^{37}$ These research papers, however, did not use firm size categories.

${ }^{38}$ In contrast to other studies in the literature, our innovation variable is not statistically significant. This might be related with the quality of information collected by the ICS in this dimension of the survey. Innovative firms are more intensive in capital, which is not compatible with the Ecuadorian production factors' (i.e., capital and labor) endowment.
} 
findings illustrate the common belief that firms with internet access are more globalized and more able to both absorb technology and access information on foreign markets than firms that do not use the internet. Web-users, therefore, have comparative advantages when deciding whether or not to become exporters and when computing the share of their total sales to be sold abroad (in comparison to non-web-users). Importing inputs is a means of absorbing technology, allowing firms to technologically advance, and foster learning opportunities on foreign conditions and network with foreign sellers (and possible buyers). However, the share of inputs imported by the firm is a determinant of export propensity only in the "baseline" and "baseline + infrastructure" models. Similar results for imported inputs were found by Dholakia and Kapur (1999) and Sjoholm (2003). Other studies also found that technology matters for export performance at the firm level, but they used different proxies for technology. Among these studies, we have Wakelin (1998) considering innovations used and produced by British firms as determinants of their export performance, Lefebvre et al. (1999) in their analysis of R\&D activities as determinants of export intensity of Canadian small and medium enterprises, and Sterlacchini (1999) and Basile (2001) studying the role of innovative activities for Italian manufacturing firms.

Focusing on the business environment variables, our findings show that firms with access to credit are more likely to become exporters and to have a larger share of their total sales exported. This is coherent with the idea that firms with loans in their portfolios may have invested more in fixed assets, technological processes, and training, which make them more able to compete in foreign markets. Moreover, firms with at least 50 percent foreign ownership are more likely to both become exporters and to have higher export intensities - this is a means of fostering their learning opportunities on foreign markets and to intensify networking with possible buyers abroad. ${ }^{39}$ In addition, firms that considered labor regulations either as a problem to their operations or as barrier to their growth were more likely to become exporters and to have a larger share of their total sales traded in foreign markets. Our interpretation is that exporters tend to be formal firms and, thus, have to deal more frequently and cope in more depth with labor regulations than non-exporters and, thus, face problems in this area that might affect their short-term operations and growth. Capacity utilization seems to positively affect export intensity of Ecuadorian firms. This was found in all models but the "baseline + infrastructure," which we believe to be explained by the fact that firms with larger problems in the three infrastructure sectors considered (e.g., energy, telecommunications and transportation) are more likely to operate at lower capacity utilization levels. Therefore, a positive and significant coefficient for capacity utilization is in line with the idea that exporters, which have already incurred on sunk costs to enter foreign markets, would persist on being exporters and the larger the capacity utilization of these firms, the larger the share of their total sales traded abroad. ${ }^{40,}{ }^{41}$ In addition, once the sunk costs to

\footnotetext{
${ }^{39}$ Acquiring information on foreign markets and networking with possible foreign buyers also represent sunk costs to the firm.

${ }^{40}$ If instead of using the Heckman selection model, a Tobit model was used to estimate export intensity, capacity utilization would have a negative sign, as can be seen in Table A4.

${ }^{41}$ For other countries, empirical studies, such as Roberts and Tybout (1997) and Bernard and Wagner (1997), found persistence in exporting by firms.
} 
enter foreign markets have been incurred, firms have an incentive to increase the intensity of their exports in order to decrease unitary sunk costs and, thus, if they increase capacity utilization, they would increase the share of products sold internationally.

Trade orientation variables show that firms whose first, second or third main trade partner is the U.S. are likely to have higher export intensities. The rationale behind the positive and significant coefficient for Main U.S. is that this country is a large and stable economy and, thus, mimes a reference on international trade. The FTA between Ecuador and the U.S., therefore, would open Ecuador's borders to the global market and positively affect exporters that already trade with the U.S. and those to whom the U.S. might become one of their three main trade partners. On the other hand, exporters whose first, second or third main trade partners belong to the Andean Community, a trade bloc Ecuador joined in 1993, are likely to have lower export intensities. We believe that the negative and significant coefficient for Main Andean Community is due to the smaller size of this market (in comparison to the American market, for example) and to the fact that the bloc is getting less open since its establishment. Thus, it leads us to consider the occurrence of trade diversion within the Andean Community: imports from more efficient producers are substituted by imports from less efficient producers due to decreases in trade tariffs among countries that belong to the bloc.

Results for infrastructure are not straightforward. None of the infrastructure variables considered were statistically significant. Our interpretation is that, even though there are infrastructure problems in Ecuador, on average, firms do not face interruptions in these services very frequently (as an annual share). Thus, this would significantly affect neither export propensities nor export intensities. These results are different from the ones found by Dollar et al. (2003) in their study on Chinese firms.

The remaining variables suggested by the theory are not significant in explaining either export propensity or export intensity of Ecuadorian firms. ${ }^{42}$

\section{CONCLUSIONS}

What enables Ecuadorian manufacturing firms to start exporting? And what are the determinants of the share of total sales exported by a firm, once the decision of becoming an exporter has been made? The aggregated trade flows between countries have been extensively studied, but the micro-determinants of international trade have been less explored. This paper applied a Heckman selection model to the 2003Investment Climate Survey (ICS) dataset to evaluate the supply-side constraints to export performance at the firm-level in Ecuador, replicating most of the results in the literature. It estimated both the probability of a firm to become an exporter (export propensity) and the share of total sales that it exports (export intensity). Results were robust and stable, which means that they were (for the core variables), with one exception (Imported inputs), similar in the four different estimations.

\footnotetext{
${ }^{42}$ Remaining variables are: Age, Listed company, Customs, and Innovation.
} 
Three important results on the determinants of the export performance of Ecuadorian firms were found. First, technology is an important driver of exports. Ecuadorian firms that perform in-house R\&D, have a quality certification (such as an ISO-certificate), access the internet, and/or import inputs are more likely to become exporters and to present higher export intensities. In-house R\&D and quality certificate were proxies for product quality, being consistent with the view that high-quality goods can access foreign markets more easily than low-quality goods. However, the cost of a quality certificate is certainly prohibitive for small and, even, medium enterprises. Webuse is a means of accessing information on foreign markets and contacting potential buyers, in addition to facilitate technology absorption. Importing inputs are also a means for a firm to foster technology absorption, while networking with foreign sellers (and potential buyers). In this regard, this paper innovates by using information on quality certificate and web-use, variables that had not been used by prior studies (probably due to the lack of data). Second, infrastructure does not matter, since none of the infrastructure variables considered were statistically significant. Lastly, trade orientation is significant, with specialized firms tending to have smaller export intensities when having the countries of the Andean Community as their main trade partners, the opposite happening if the U.S. is their main trade partner.

It is also important to highlight that robust and stable relationships for export propensity and export intensity were also found with four other explanatory variables. First, large firms present better export performance than small firms. This result is consistent with the views of decreasing fixed costs, market selection of successful firms in domestic markets to be more prone to compete in international markets, and that a minimum firm size is necessary to make a firm able to incur the sunk costs associated with entering foreign markets. Second, firms with at least 50 percent foreign ownership are more likely both to become exporters and to higher export intensities, facts that can be related to the intensification of learning opportunities abroad and networking with foreign buyers. Third, if a firm considers labor regulations a problem to its business operations and growth, it is more likely to become an exporter. This is probably associated with the fact that exporters tend to be formal firms and, thus, deal more frequently and cope in more depth with regulations than non-exporters. Fourth, credit access is another determinant of a firm's export performance in Ecuador. Finally, capacity utilization positively affects export intensity - a finding coherent with the view of decreasing sunk and fixed costs. 


\section{REFERENCES}

Arnold, J.M., and K. Hussinger (2004) "Export behavior and firm productivity in German manufacturing-A firm-level analysis.” Center for European Economic Research, discussion paper No. 04-12.

Bhagwati, J. (2002) Free trade today. Princeton, NJ: Princeton University Press.

Barrios, S., H. Gorg, and E. Strobl (2003) "Explaining firms' export behaviour: the role of R\&D and spillovers." Oxford Bulletin of Economics and Statistics 4, pp.475496.

Bechetti, L. and S. Rossi (2000) "The positive effect of industrial districts on the export performance of Italian firms.” Review of Industrial Organization 16(1), pp.53-68.

Bernard, A., and J. Jensen (1999) "Exceptional exporter performance: cause effect or both?” Journal of International Economics 47, pp.1-25.

Bernard, A., and J. Wagner (1997) "Exports and success in German and manufacturing." Weltwirtschaftliches Archiv 133(1), pp.134-157.

Bleaney, M. and K. Wakelin (2002) "Efficiency, innovation and exports." Oxford Bulletin of Economics and Statistics 64(3), pp.3-15.

Boileau, M., and M. Normandin (1999) "Capacity utilization and the dynamics of business cycle fluctuations.” Center for Research on Economic Fluctuations and Employment, working paper No. 92.

Bonaccorsi, A. (1992) "On the relationship between firm size and export intensity." Journal of International Business Studies 23, pp.605-635.

Braunerhjelm, P. (1996) "The relation between firm-specific intangibles and exports." Economics Letters 53, pp.213-219.

Cassiman, B., and E. Martinez-Ros (2003) "Innovation driving export performance: evidence from the Spanish manufacturing.” Proceedings of the XIX Jornadas de Economía Industrial.

Clarke, G. (2001) "Bridging the digital divide: How enterprise ownership and foreign competition affect internet access in Eastern Europe and Central Asia.” World Bank Policy Research Working Paper No. 2629.

Cordoba, S.F., S. Laird, J. Maur, and J.M. Serena (2005) "Chapter 2: Adjustment costs and trade liberalization.” In Cordoba, S.F., and S. Laird (ed.) “Coping with trade reforms: A developing-country perspective on the WTO industrial tariff negotiations.” United Nations Conference on Trade and Development/Trade Analysis Branch.

Dholakia, R.H., and D. Kapur (1999) "Trade, technology and wage effects of economic policy reforms on the India private corporate sector.” The India Journal of Labour Economics 42(4), pp.981-992.

Dholakia, R.H., and D. Kapur (2004) "Determinants of export performance of Indian firms-A strategic perspective." Indian Institute of Management Ahmedabad, working paper 2004-08-01.

Dollar, D., M. Hallward-Driemeier, and T. Mengistae (2003) "Investment climate, infrastructure and trade: a comparison of Latin American and Asia.” Prepared for the Conference of Sector Reforms in Latin America. Stanford Center for International Development, November 13-15, 2003. 
Escribano, A., and J.L. Guasch (2005) "Assessing the impact of the investment climate on productivity using firm-level data: methodology and the cases of Guatemala, Honduras, and Nicaragua.” World Bank Policy Research Working Paper No. 3621.

Fagerberg, J. (1988) “International competitiveness.” Economic Journal 98, pp.355-374. Fajnzylber, P. (2004) "Learning before or from exporting: evidence from Brazilian manufacturing firms.” Mimeo.

Fonseca, D. (2003) "Many hands make light work." Inter-American Development Bank Micro Enterprise Americas Magazine, Autumn Ed.

Foroutan, F. (1998) "Does membership in a regional preferential trade arrangement make a country more or less protectionist?” The World Economy 21(3), pp.305-335.

Glejser, H., A. Jaquemin, and J. Petit (1982) "Exports in an imperfect competition framework: an analysis of 1,446 exporters." Quarterly Journal of Economics 94, pp.507-524.

Greenaway, D., N. Sousa, and K. Wakelin (2004) "Do domestic firms learn to export from multinationals?” European Journal of Political Science 20, pp.1027-1043.

Harberger, A.C. (1959) "Using resources at hand more effectively." (The Cairo Lectures, 1959). Reprinted in International Trade and Economic Development, 1988, pp.17-54.

Heckman, J. (1976) "The common structure of statistical models of truncation, sample selection, and limited dependent variables and a simple estimator for such models." Annals of Economic and Social Measurements 5, pp.475-492.

Helpman, E., and P.R. Krugman (1999) "The structure of foreign trade." Journal of Economic Perspectives, Spring 1999, pp.121-1 44.

Hirsch, S., and I. Bijaoui (1985) "R\&D intensity in export performance: a micro view." Weltwirtschaftliches Archiv 121, pp.138-251.

Hoekman, B., and B.S. Javorcik (2004) "Policies facilitating adjustment to trade liberalization.” World Bank Policy Research Working Paper No. 3441.

Ito, K., and V. Pucik (1993) "R\&D spending, domestic competitions, and export performance of Japanese manufacturing firms.” Strategic Management Journal 14, pp.61-75.

Krugman, P.R., and M. Obstfeld (2003) International economics - Theory and policy. Reading, MA: Addison-Wesley. Sixth Edition.

Kumar, N., and N. Siddharthan (1994) "Technology, firm size and export behavior in developing countries: the case of Indian enterprises." Journal of Development Studies 31, pp.289-309.

Lefebvre, E., L. Lefebvre, and M. Bourgault (1998) "R\&D-related capabilities as determinants of export performance.” Small Business Economics 10, pp.365-377.

Lefebvre, E., and L. Lefebvre (2001) "Innovative capabilities as determinants of exports behavior and performance: a longitudinal study of manufacturing SMEs." In: Kleinknecht, A. and P. Mohnen (ed.), Innovation and Firm PerformanceEconometric Exploration of Survey Data.

Lora, E.A., and C. Pagés-Serra (2003) "Labor market regulations and institutions." In: The economic and social progress in Latin America-2004 Report. Washington, D.C.: Inter-American Bank for Development. 
MICIP (Ministério de Comercio Exterior, Industrialización, Pesca y Competitividad de Ecuador) (2002) “Diganóstico de la pequeña y mediana industria.” Mimeo.

Nassimbeni, G (2001) "Technology, innovation capacity, and the export attitude of small manufacturing firms: a Logit/Tobit model.” Research Policy 30, pp.245-262.

OECD (2004) "Trade and structural adjustment." Organization for Economic Cooperation and Development, Paris, TD/TC (2004) 10.

Pant, M. (1993) "Export performance, transitional corporations and the manufacturing sector: a case study of India.” Indian Economic Review 28(1), pp.41-54.

Pavitt, K. (1984) "Sectoral patterns of technical change: towards a taxonomy and a theory.” Research Policy 13, pp.342-373.

Porter, M. (1990) The Competitive advantage of nations. New York: The Free Press.

Schlegelmilch, B.B., and J.N. Crook (1988) "Firm-level determinants of export intensity." Managerial and Decision Economics 9, pp.291-300.

Scherer, F.M., and D. Ross (1990) Industrial market structure and economic performance. Boston: Houghton Mifflin.

Ramstetter, E. (1999) "Trade propensities and foreign ownership shares in Indonesian manufacturing.” Bulletin of Indonesian Economic Studies 35.

Redding, S., and A.J. Venables (2003) "Geography and export performance: external market access and internal supply capacity.” NBER, Working Paper No. 9637.

Roberts, M., and J. Tybout (1997) "The decision to export in Colombia: an empirical model of entry with sunk costs.” American Economic Review 87, pp.545-564.

Romijn, H. (1997) "Acquisition of technological capability in development: a quantitative case study of Pakistan's capital goods sector." World Development 25, pp.359-377.

Roper, S., and J.H. Love (2001) "The determinants of export performance: panel data evidence for Irish manufacturing plants.” NIERC working paper No. 69.

Roper, S., and J.H. Love (2002) "Innovation and export performance: evidence from the UK and German manufacturing plants.” Research Policy 31, pp.1087-1102.

Rosenberg, N. (1969) "The direction of technological change: inducement mechanism and focusing devices.” Economic Development and Cultural Change 18(1), pp.124.

Rosenberg, N. (1974) "Science, invention and economic growth.” The Economic Journal 84(333), pp.90-108.

Sjoholm, F. (2003) "Which Indonesian firms export? The importance of foreign networks.” Papers in Regional Sciences 82, pp.333-350.

Smith, V., E.S. Madsen, and M. Dilling-Hansen (2002) "Export performance and investment in R\&D.” The Danish Institute for Studies in Research and Research Policy, working paper No. 2002/04.

Sterlacchini, A. (1999) "Do innovative activities matter to small firms in non-R\&Dincentive industries? An application to export performance.” Research Policy 28, pp.819-832.

Tobin, J. (1956) "Estimation of relationships for limited dependent variables." Econometrica 26, pp.24-36.

Viner, J. (1950) The customs union issue. New York. Carnegie Endowment for International Peace. 
Wagner, J. (1995) “Exports, firm size, and firm dynamics.” Small Business Economics 7, 29-39.

Wagner, J. (2001) “A note on firm size-export relationship.” Small Business Economics 17, pp.229-237.

Wakelin, K. (1998) "Innovation and export behavior at the firm level." Research Policy 26, pp.829-841.

Wignaraja, G. (1998) Trade liberalization in Sri Lanka: exports, technology and industrial policy. New York: MacMillan Press Ltd..

Wignaraja, G. (2001) "Firm size, technological capabilities and market-oriented policies in Mauritius.” UNU/INTECH Working Paper No. 1. Maastricht: UNU/INTECH.

Wignaraja, G., and G. Ikiara (1999) "Adjustment, technological capabilities and enterprise dynamics in Kenya.” In: Lall, S. (ed), The Technological Response to Import Liberalization in Subsaharan Africa. London: MacMillan Press Ltd., pp.57-111.

Willmore, L. (1992) “Transnational and foreign trade: evidence from Brazil.” Journal of Development Studies 28(2), pp.314-335.

World Bank (2004) “Ecuador-Investment Climate Assessment.” Report No. 31900. 
Figure A1. Ecuadorian firms: box plot for employment in 2001

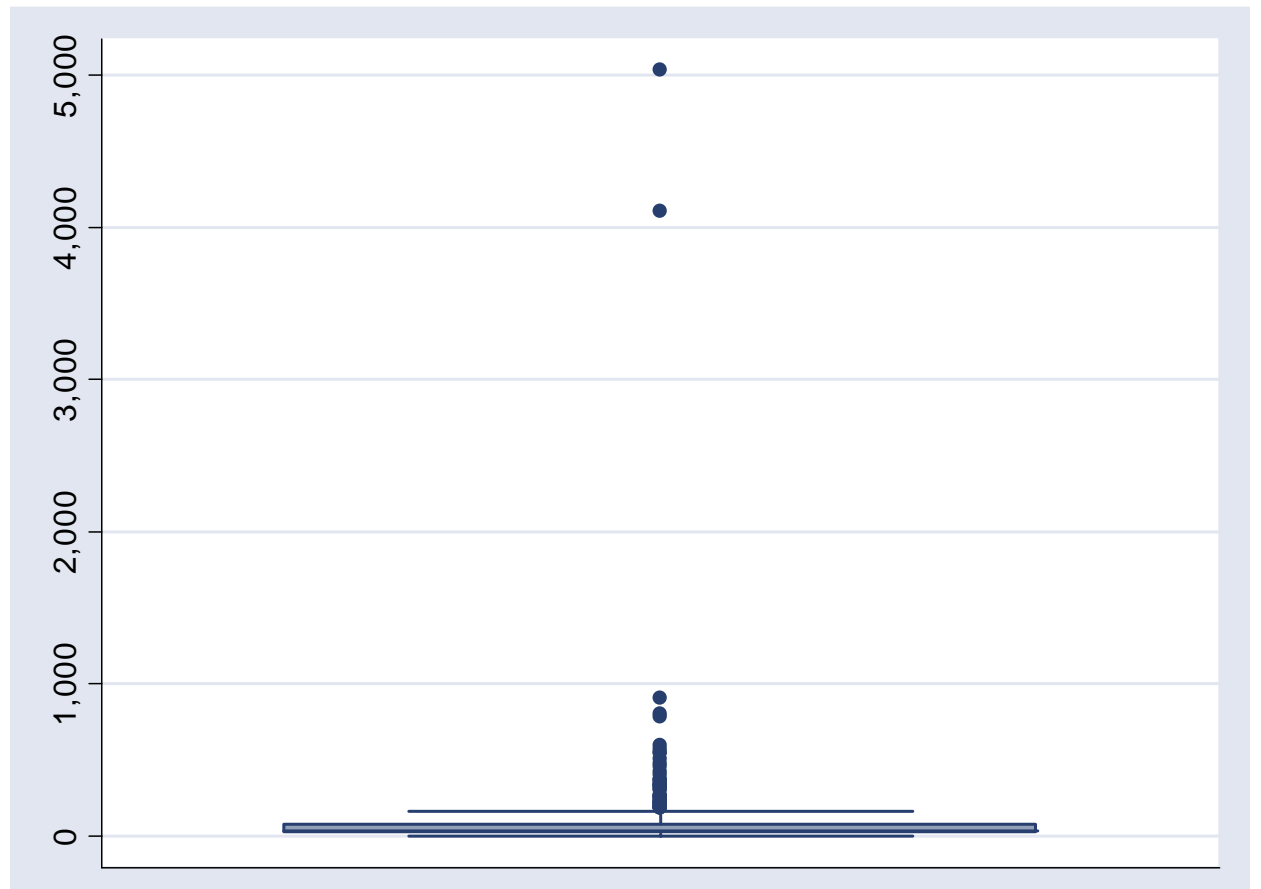

Note: Box plot is a graph of the five-number summary in which the central box spans the first and the third quartiles, the line in the box marks the median, lines extend from the box out to the smallest and largest observations and "dots" represent outliers.

Source: ICS-Ecuador.

Table A1. Descriptive statistics

\begin{tabular}{llrrrr}
\hline Set & Variable & Mean & Standard Deviation & Minimum & Maximum \\
\hline Firm & Age & 21.13 & 15.53 & 1.00 & 98.00 \\
Idiosyncratic & Small & 0.34 & 0.47 & 0.00 & 1.00 \\
Characteristics & Medium & 0.34 & 0.47 & 0.00 & 1.00 \\
& Large & 0.33 & 0.47 & 0.00 & 1.00 \\
\hline Technology & R\&D & 0.36 & 0.48 & 0.00 & 1.00 \\
& Innovation & 0.51 & 0.50 & 0.00 & 1.00 \\
& Quality certification & 0.16 & 0.36 & 0.00 & 1.00 \\
& Web-use & 0.55 & 0.50 & 0.00 & 1.00 \\
& Imported inputs & 39.91 & 39.00 & 0.00 & 100.00 \\
\hline Business & Listed company & 0.53 & 0.50 & 0.00 & 1.00 \\
Environment & Loan & 0.72 & 0.45 & 0.00 & 1.00 \\
& Foreign ownership & 0.08 & 0.27 & 0.00 & 1.00 \\
& Capacity utilization & 66.01 & 22.90 & 5.00 & 100.00 \\
& Customs & 0.41 & 0.49 & 0.00 & 1.00 \\
& Labor regulations & 0.29 & 0.46 & 0.00 & 1.00 \\
\hline Trade & Main U.S. & 0.09 & 0.28 & 0.00 & 1.00 \\
& Main Andean Community & 0.20 & 0.40 & 0.00 & 1.00 \\
\hline Infrastructure & Energy & 0.03 & 0.09 & 0.00 & 1.00 \\
& Telecom & 0.03 & 0.11 & 0.00 & 1.00 \\
& Transportation & 0.01 & 0.04 & 0.00 & 0.82 \\
\hline
\end{tabular}

Note: Capacity utilization $(\mathrm{N}=419)$, Imported inputs and Energy $(\mathrm{N}=430)$, and all other variables $(\mathrm{N}=432)$. 
Table A2. Correlation matrix

\begin{tabular}{|c|c|c|c|c|c|c|c|c|c|c|c|c|c|c|c|c|c|}
\hline & Age & Med. & Large & R\&D & Innov. & $\begin{array}{c}\text { Listed } \\
\text { company }\end{array}$ & Loan & $\begin{array}{l}\text { Quality } \\
\text { certif. }\end{array}$ & $\begin{array}{c}\text { Web- } \\
\text { use }\end{array}$ & $\begin{array}{c}\text { Foreign } \\
\text { owner. }\end{array}$ & $\begin{array}{c}\text { Import } \\
\text { inputs }\end{array}$ & $\begin{array}{c}\text { Capacity } \\
\text { utilizat. }\end{array}$ & U.S & $\begin{array}{l}\text { Andean } \\
\text { Com. }\end{array}$ & Energy & Telecom & Transp \\
\hline Age & 1.000 & & & & & & & & & & & & & & & & \\
\hline Med. & -0.048 & 1.000 & & & & & & & & & & & & & & & \\
\hline Large & 0.251 & -0.507 & 1.000 & & & & & & & & & & & & & & \\
\hline R\&D & -0.006 & -0.034 & 0.010 & 1.000 & & & & & & & & & & & & & \\
\hline Innov. & -0.003 & 0.028 & 0.122 & 0.144 & 1.000 & & & & & & & & & & & & \\
\hline Listed company & 0.101 & -0.043 & 0.183 & -0.026 & 0.090 & 1.000 & & & & & & & & & & & \\
\hline Loan & 0.027 & -0.002 & 0.094 & 0.068 & 0.083 & 0.005 & 1.000 & & & & & & & & & & \\
\hline Quality certif. & 0.138 & -0.154 & 0.240 & -0.025 & 0.010 & 0.138 & 0.006 & 1.000 & & & & & & & & & \\
\hline Web-use & 0.071 & -0.166 & 0.368 & -0.028 & 0.156 & 0.160 & 0.066 & 0.179 & 1.000 & & & & & & & & \\
\hline Foreign owner. & 0.011 & -0.071 & 0.191 & -0.029 & -0.057 & 0.086 & -0.074 & 0.057 & 0.114 & 1.000 & & & & & & & \\
\hline Import inputs & 0.182 & -0.013 & 0.107 & -0.052 & 0.101 & 0.146 & 0.137 & 0.115 & 0.086 & 0.107 & 1.000 & & & & & & \\
\hline Capacity utiliz. & -0.062 & -0.114 & 0.139 & -0.003 & -0.002 & 0.058 & 0.111 & 0.085 & 0.095 & 0.037 & 0.069 & 1.000 & & & & & \\
\hline U.S. & 0.071 & -0.097 & 0.221 & 0.152 & 0.057 & 0.018 & 0.034 & 0.177 & 0.146 & 0.043 & -0.105 & -0.031 & 1.000 & & & & \\
\hline Andean Com. & 0.155 & -0.109 & 0.281 & 0.078 & 0.054 & 0.072 & 0.133 & 0.147 & 0.156 & 0.117 & 0.191 & 0.048 & 0.132 & 1.000 & & & \\
\hline Energy & -0.025 & 0.023 & 0.069 & -0.027 & 0.107 & 0.018 & 0.094 & -0.041 & 0.011 & 0.045 & 0.045 & -0.035 & -0.057 & -0.015 & 1.000 & & \\
\hline Telecom & 0.006 & 0.071 & -0.025 & 0.002 & 0.106 & 0.141 & 0.132 & -0.062 & 0.050 & -0.001 & 0.049 & -0.122 & 0.007 & -0.046 & 0.082 & 1.000 & \\
\hline Transport & -0.016 & -0.042 & 0.085 & -0.047 & 0.057 & -0.020 & 0.027 & -0.009 & 0.055 & 0.013 & 0.052 & 0.038 & -0.008 & -0.024 & 0.065 & -0.014 & 1.000 \\
\hline
\end{tabular}


Table A3. Probit estimation on the propensity to export of Ecuadorian firms

\begin{tabular}{llcc}
\hline \multirow{2}{*}{ Set } & Variable & \multicolumn{2}{c}{ Baseline } \\
\cline { 2 - 3 } & & Coefficient & z-value \\
\hline-- & Constant & $-1.41416^{* * *}$ & -4.28 \\
\hline Firm & Age & 0.00803 & 1.64 \\
Idiosyncratic & Medium & 0.05418 & 0.29 \\
Characteristics & Large & $0.68349^{* * *}$ & 3.59 \\
\hline Technology & R\&D & $0.35086^{* *}$ & 2.35 \\
& Innovation & 0.13993 & 0.89 \\
& Quality certification & $0.42969^{* *}$ & 2.22 \\
& Web-use & $0.39193^{* *}$ & 2.42 \\
\hline Business & Imported inputs & 0.00257 & 1.15 \\
Environment & Listed company & 0.15784 & 1.02 \\
& Loan & $0.35766^{* *}$ & 2.04 \\
\hline-- & Foreign ownership & $0.63125^{* * *}$ & 256 \\
\hline
\end{tabular}

Note: $\quad * *$ Significant at a 5 percent level. ${ }^{* * *}$ Significant at a 1 percent level. The wood and furniture sector is the omitted category for industry. Pichincha is the omitted category for region.

Table A4. Tobit estimation on the export intensity of Ecuadorian firms

\begin{tabular}{llcc}
\hline \multirow{2}{*}{ Set } & Variable & \multicolumn{2}{c}{ Baseline } \\
\cline { 2 - 3 } & & Coefficient & t-value \\
\hline-- & Constant & $-52.55178^{* * *}$ & -3.01 \\
\hline Firm & Age & 0.21866 & 1.12 \\
Idiosyncratic & Medium & 6.75922 & 0.80 \\
Characteristics & Large & $31.60391^{* * *}$ & 3.85 \\
\hline Technology & R\&D & $15.91406^{* *}$ & 2.51 \\
& Innovation & 6.66605 & 1.00 \\
& Quality certification & $19.61818^{* *}$ & 2.45 \\
\hline Business & Web-use & $15.41286^{* *}$ & 2.20 \\
Environment & Listed company & 5.11447 & 0.77 \\
& Loan & $20.79568^{* *}$ & 2.70 \\
& Foreign ownership & $32.59806^{* * *}$ & 3.32 \\
\hline-- & & -0.14017 & -1.00 \\
\hline
\end{tabular}

Note: ${ }^{* *}$ Significant at a 5 percent level. ${ }^{* * *}$ Significant at a 1 percent level. The wood and furniture sector is the omitted category for industry. Pichincha is the omitted category for region. 